
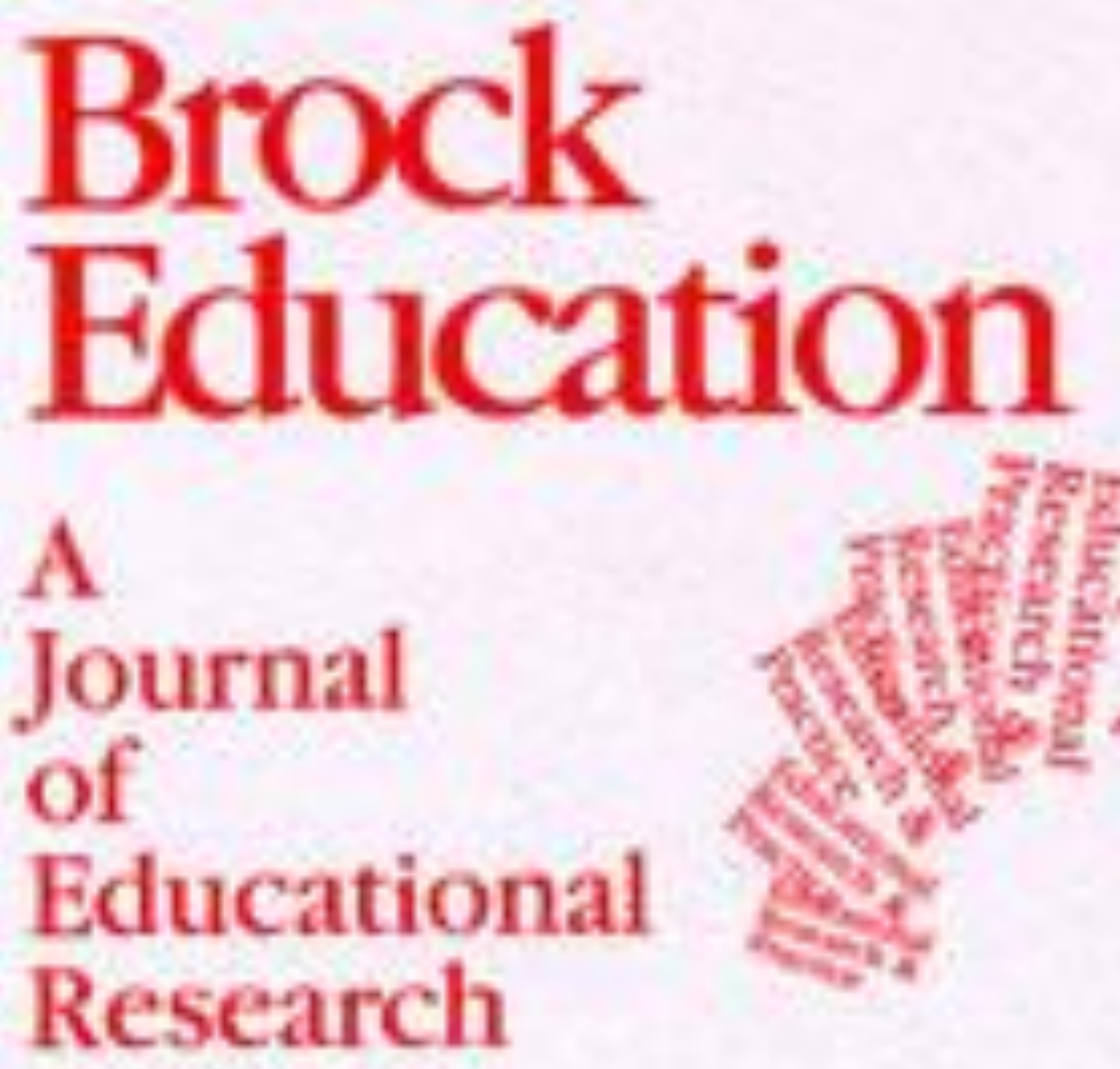

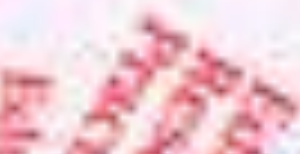

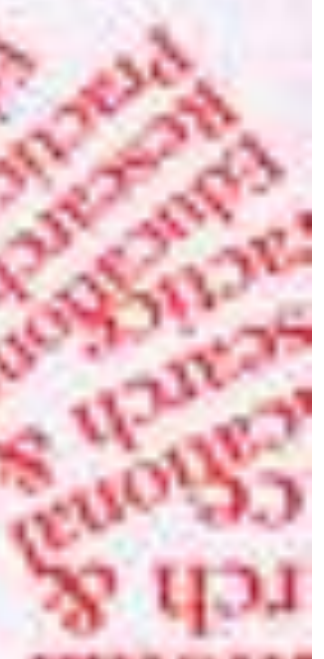

\&

Practice

pruob!

$40 j$ ${ }^{\circ} \mathrm{HOg}_{\mathrm{O}}$

Volume 13 (1) . Fitp $>003$

$$
\begin{aligned}
& \text { S }
\end{aligned}
$$

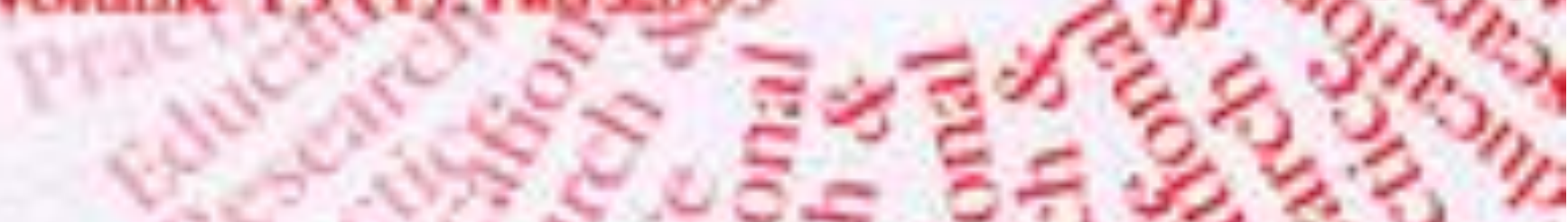

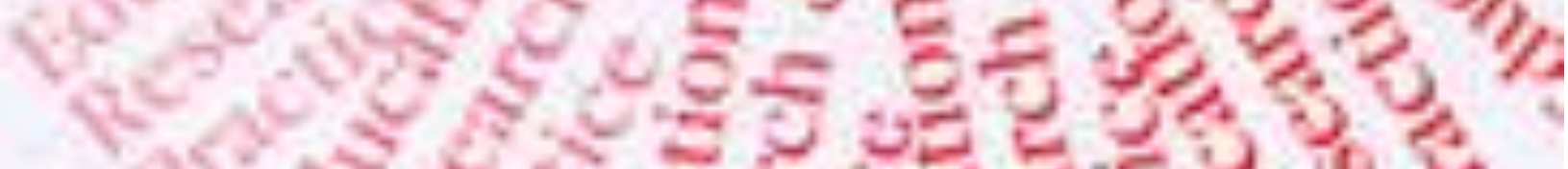

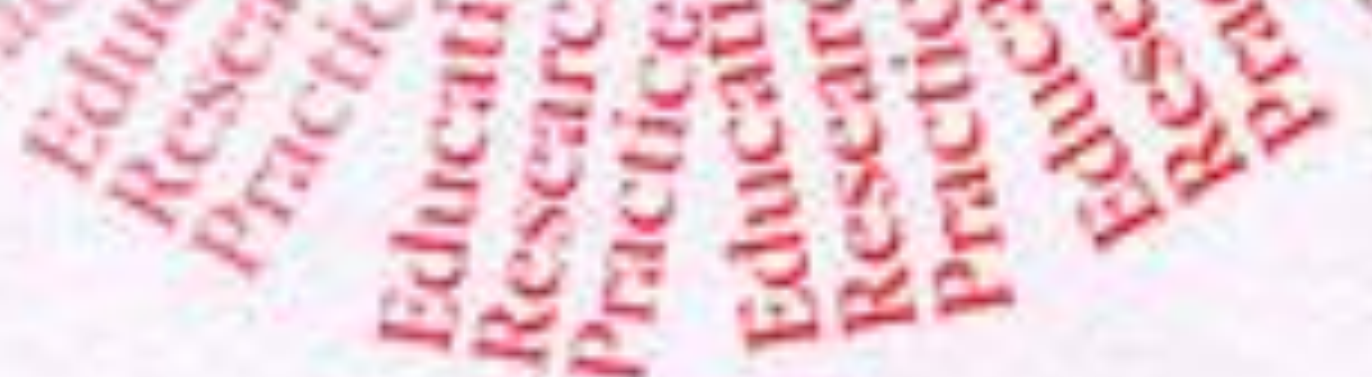


Brock Education

Vol. 13, No. 1, 2003

\title{
The Thesis Journey: Travelling with Charley'
}

\author{
Ardra L. Cole \\ Ontario Institute for Studies in Education \\ University of Toronto
}

I chose the title of my talk for two reasons. The first part connects with the book, The Doctoral Thesis Journey, which I co-edited with David Hunt in 1994. The journey metaphor still works for me as a way to talk about the thesis process. The sub-title, Travelling with Charley, is borrowed from an account of a particular kind of journey-John Steinbecks's road trip across the United States with his standard poodle, Charley, chronicled in his classic novel, Travels with Charley. The sub-title connects with a new book that I am working on now, with the working title, Of Dogs and Dissertations: Notes on Thesis Writing and Life.

You don't have to have a dog in your life or love a dog to connect with what I am going to say, but it might help. So I invite you to pause for a minute and invite a dog you have known or currently know to come forward in your mind. Let him or her be here with you for the next 40 minutes or so while we think together about what we can learn about thesis writing (among other things) from these wonderful creatures. If you are not inclined to want to invite a dog to lunch, then a horse will do, or a cat, or a rabbit.

No, I haven't lost my mind and I am not joking. There is much to be learned from dogs if we learn to adopt what Lous Heshusius (1994) would call, a "participatory mode of consciousness" and if we engage with them with patience, openness, and feeling. To quote Suzanne Clothier in her extraordinary book, Bones Would Rain from the Sky, "To travel in the company of animals is to walk with angels, guides, guardians, jesters, shadows and mirrors" (2002, p.11).

Suzanne Clothier describes her and her husband's wedding ceremony, which took place in a pasture on their farm and which, of course, included their seven dogs. As part of the ceremony they called forward each dog in turn as an embodiment of qualities and characteristics that they, the bride and groom,

Dr. Ardra Cole is Professor and Co-director of the Centre for Arts-informed Research in the Department of Adult Education and Counselling Psychology at OISE/UT. Her research, teaching, and writing are mainly in the area of qualitative research methodologies, particularly life history and arts-informed approaches. Among her recent books are Lives in Context: The Art of Life History Research, The Art of Writing Inquiry, and Provoked by Art: Theorizing Art-informed Research. She is also co-editor of The Doctoral Thesis Journey: Reflections from Travellers and Guides.

${ }^{1}$ Dr. Reginald B. Moase Invitational Address delivered at the $21^{\text {st }}$ Annual Graduate Students' Conference, Faculty of Education, Brock University, May 10, 2003. 
hoped to emulate in their marriage: gentleness, maturity, determination, gracefulness, faithfulness, beauty, courage, playfulness, and so on. "In calling our dogs to us and naming their gifts and lessons," she says, "we acknowledged what they helped to create in our lives and honored their role in our lives as teachers" (p. 275). Earlier in the book she states, "Of all the gifts that animals can offer, perhaps the greatest is... [the] opportunity to delve deep inside ourselves. Without judgment or timetables, with patience and an amazing capacity for forgiveness, animals are the ideal guides through our inner landscapes" (p. 12).

I take inspiration from Suzanne Clothier when I think about the thesis process. We have much to learn from dogs about thesis writing and about life. Many of the qualities they embody are lessons to thesis writers: devotion, noseto-the-ground discipline, presence, attunement, honesty, patience, humour, companionship, curiosity, dignity, dogged persistence, joy, creativity, forgiveness, acceptance, non-judgement, a basic wisdom about the need for physical, emotional, and intellectual balance, and of course love, to name but a few.

The following three dog vignettes are from my in-progress manuscript. Each story exemplifies one or more of the qualities to be honoured in the thesis process. After each story I more directly explore the qualities and their role in the thesis process. Then I offer a list of top twenty travel tips for the thesis journey. I hope what I have to share with you is both enjoyable and helpful. The journey on which you all have embarked is a demanding one on many levels. It is as Corrine Glesne and Allan Peshkin (1992, p. 179) say about qualitative research "an odyssey into our discipline, our practice, and perhaps our souls. We cannot be sure of what we will find, but we invariably get caught up in the search." You are all at different points along the way and are likely grappling with different issues, problems, and concerns and you likely have myriad questions. I hope I will speak to at least some of what is on your mind. So without further ado, give that dog that has joined you a gentle stroking and I will begin.

\section{Vignette 1}

I sit at my computer staring at the screen, searching the far reaches of my mind for words to help me untangle the thoughts in my head. The harder I try to loosen up the ideas enough to work with them, the tighter the knot becomes, until I lose sight altogether of even the kind of words I am looking for let alone specific ones. I sigh in frustration and, conscious 
of the nagging pain in my right shoulder where I hold all my tension, I move it in a slow circular motion. As I twist my head to the right in an attempt to stretch my neck muscles and release more tension, my gaze falls to the floor a metre or so from my desk. I pause and whisper his name. Thump, thump, he replies. I say it again, louder and with an inflection that he recognizes as loving (I think). More and faster thumping accompanied by an expectant yet quizzical cock of the head. I slide from my chair to the floor and sidle over to his mat. His brown velvet eyes watch my approach. A few more thumps of the tail against the hardwood floor and then, ever so subtly, he shifts his weight. Before I complete my short journey across the floor he is on his back, all four paws in the air. I lay both hands on his soft, warm belly and begin a gentle caress. At my touch, his head flops to the side in a gesture of complete trust and assent. My hand movements are slow, gentle, rhythmic. I feel my body relax, tension ease. My search for words seems unimportant. He drops a front and back paw and shifts his weight again. $\mathrm{He}$ is on his side now and my strokes lengthen. Beginning at the top of his head and moving along his side and toward his tail, my hands glide across the surface of his fur. Just as I reach his hindquarter, he gently stretches, then slightly raises a back leg. It is an invitation. I follow his request and make a detour to gently rub the soft, downy crease between his leg and belly. He lets out a long and deep dog-sigh of utter contentment and in-the-moment gratification. His leg drops once again and I continue my light massage. I am aware of my breathing-slow and centred. Its rhythm has become synchronized with his. I am almost in a meditative state. A few minutes more and his gentle breathing has become a soft, purring snore. I pause to take in this moment of complete surrender before I slip away and return to my computer. Reseated, my fingers dance across the top of the keyboard-a slow skater's waltz. I am present with my thoughts. Words come.

Writing a thesis is not just a work of the mind. It is an act of attunement that depends on the interrelated engagement of mind, body, emotion, and soul. As you work to conceptualize, clarify, and articulate ideas, as you strive to make meaning of mounds of data, as you yearn and struggle in earnest 
for moments of revelation and insight, and as you desperately search for exactly the right words to say what seems so clear in your head and heart, you are engaged in an agonizingly elusive process of tough thinking and sense-making. Despite good intentions and strong will, sometimes you just have to surrender your reliance on your conscious, rational mind. Learning-deep insight and creative thinking, or what Stephen Nachmanovitch (1990), in his book, Free Play: Improvisation in Life and Art, calls "ripening"-requires mulling space. Ripening, says Nachmanovitch, takes place when our attention is directed elsewhere. In The Writing Life, Annie Dillard (1989) makes a comparison between splitting wood and writing. She tells a story about spending days and nights of agonizing cold in a cabin to which she had retreated to finish a writing project. She did not know how to split wood sufficiently well to keep a heatradiating fire going. After mornings of what she described as "chipping flints" and "attacking the wood" and nights of trying to figure out how it was done properly, the answer came to her one night in a dream. "You aim at the chopping block, not at the wood," the dream told her. "Treat the wood as a transparent means to an end, by aiming past it." And so it is with writing she asserts. "Aim for the chopping block. If you aim for the wood, you will have nothing. Aim past the wood, aim through the wood; aim for the chopping block." Incidentally, Nachmanovitch $(1990$, p. 157) has this to say about dreams:

Creative people, even when sleeping, are working and playing on their questions. Life is full of surprises when we're asleep. There is something in us constantly wanting to come out, and it seems to emerge more easily when we let go of the strictures (hope and fear) of consciousness.

Often, sitting in front of a computer or at a desk with pen poised over (blank) paper does more to stifle creative thinking than inspire it. It is more likely the case that your "best" thoughts, conceptual links, insights, revelations, discoveries, "ahas" will come to you when you least expect them. Sometimes the best thing you can do to move forward is to move away-from your desk, from conscious attention to your work, and from your rational struggles with and for logic. Sometimes the best thing you can do to advance your thinking is to unfetter your intellect and engage other parts of yourself. Go for a walk, take a bath, cook a gourmet meal, take in a movie or concert, paint a room, spend time with your dog. 


\section{Vignette 2}

It's raining, hard; the kind of rain you hope for in early spring, the kind you hope will wash away the debris from urban winter and give spring green a nudge forward. I am dressed for the weather-waterproofed from head to toe.

Nevertheless, my plan is for a shorter-than-usual walk; it's late and it's cold along with the wet. We move quickly, wending our way along the familiar sidewalks of our neighbourhood, pausing only long enough for cursory investigations of interesting smells and littered remains of lunch bags, fast food containers, the odd bone or food scrap likely dropped by a scavenger on the run. We zigzag from one side of our neighbourhood to the other ducking down back laneways, taking shortcuts, moving steadily forward through the pouring rain. He seems quite happy with our faster-than-usual pace, and for a while I think my plan for a shortened walk is going to work. And then I lead us around a corner and onto the main commercial street of our neighbourhood. I realize my mistake too late; it's garbage night.

During the day and evening this street is a bustle of activity, drawing shoppers to any number of restaurants, pubs, bakeries, butcher shops, fruit and vegetable markets, and specialty food boutiques. Now, the street is more or less deserted except for a few lingering bar and restaurant patrons and the occasional dog walking duo. Now, on the abandoned sidewalk slick with rain and under the glow of the streetlights, sits the week's garbage. Curbside in front of every food establishment are mounds of polyethylene garbage bags filled to capacity and tied close, large blue and green plastic waste bins on wheels lined up in rows, and stacks of collapsed and bundled cardboard boxes. I heave a sigh of defeat as I look up the street; garbage as far as I can see.

I could turn around and lead us back home the way we came but, because I have a rule about never retracing steps, I give a signal that moves us forward. The rain has not let up and I am aware that a chilly dampness has settled in my bones. I feel a slight tug at the end of the leash and look down to see his brown nose, wet and glistening, held high in 
the air twitching, honing in on what must seem like a veritable olfactory feast. I give in knowing that it is futile, not to mention unfair, to engage in a battle of wills that I could only win with brute force. I follow him to the first stop, the butcher shop. Bundle after bundle of flattened cardboard boxes are tied and neatly stacked curbside opposite the store entrance; twenty-six in all, I am about to discover. The printing still visible on the rain-soaked cardboard reads like a delivery list: Chicken Coop Poultry Products, Grade A Meats, Brown's Beef. "There couldn't possibly be any scent left," I think half-aloud with a gentle tug, bidding us forward. We are at bundle number four.

With the kind of methodical precision of a forensic detective, he passes his nose over every square centimetre of cardboard within reach. Heedless of my suggestions that it is time to continue on our way; oblivious to the rain pouring down and soaking both of us, and even despite bribes of yummy treats from my coat pocket, he persists with his task-methodically, meticulously, relentlessly. There is nothing as important right now. This job has priority over everything. No shortcuts, no distractions; just nose-to-the-ground (or box) persistence, regardless. From beginning to end, top to bottom, he perseveres. Sixteen and counting. "What? He has skipped three bundles." We're into the twenties now; the end is in sight. I walk a few steps ahead past the end of the line in hopeful anticipation of moving on. Finally, number twenty-six. He pauses at the end of the last bundle as if to review his work and we walk on. Not ten steps away I feel the leash strain in my hand and groan upon realization that he has turned back and is headed toward the cardboard again as if following up on a second thought. Again, I follow, rain dripping from my hood, down my face, and trickling into my mouth. Back we go straight to the three bundles passed over first time around. With the same kind of finical precision as before he gives each one a thorough going-over, then stands back and does a final survey of the entire pile before working up a long, full, satisfying shake throwing water in every direction. Finally, ready to move on, we pick up the pace and make our way farther along the sidewalk. As we approach the pile of garbage bags stacked opposite the bar and grill I shiver in anticipation. It will be a late night. There is much to be done. 
A thesis is completed through dogged persistence and determination. Be prepared for hard work and dedication to the task. Writing a thesis is hard work that is unlike any other academic task. It is not just another course paper. It is a book, believe it or not, and it requires a different kind and level of commitment: focused and sustained. Doing course work is the easy part of a degree program - which is why there is such a high percentage of ABDs (All But Dissertation) or ABTs (All But Thesis). A study reported on in Berkowitz (2003) indicates $\mathrm{PhD}$ completion rates of $55.1 \%$ and Master's completion rates of $70.6 \%$ in the Social Sciences.

A thesis is written one word at a time. Words string together to make sentences which compose paragraphs which fill pages which add up to chapters. Working with dedication and discipline toward deadlines (working in 3-D) will carry you a long way. Establish and stick to a schedule. Write every day for a set period of time. Set goals and stick to them, regardless. For example, 3 pages a day x 6 days a week $=18$ pages a week x 10 weeks $=180$ pages-not all of which will be usable but nevertheless. Persist towards achieving those three pages and reward yourself when it comes easy. And on those days when you just can't seem to put a coherent sentence together, there is always editing the previous day's work, proofreading last week's writing, gleaning field notes and transcripts, updating your reference list, polishing and fiddling. The longer a project is stretched out, the greater the chances of losing interest. As Stephen King (2000) would say, the mythical muse is not going to get the work done; she can only supply the inspiration.

And then just when you think you've finished look again, go deeper, look for overarching points to theorize. Try to answer the questions: What is your thesis about? What can a reader learn from it? To answer, stand back and look at it from a distance. If the answer to those questions is not apparent then it needs another revision. In Writing Down the Bones, Natalie Goldberg (1986, p. 103) says this of writing in general: "Sometimes when you think you are done, it's just the edge of the beginning."

Inevitably, life will get in the way. While it is important to acknowledge and attend to life events and challenges, it is just as important to know when they have become excuses to stop work. You will reach a point in the thesis process where you realize that, in order to do the kind of deep thinking, mulling, and writing required you must make your thesis your priority over all else (except your dog of course). You will need to eliminate distractions and find Virginia Woolf's equivalent of "a room of your own," a place where, in Gail Griffin's (1992, p. 230) words, "the significance of one's work is assumed and takes priority over all else." Annie Dillard (1989, p. 26) describes how she goes about creating "unappealing workplaces." No matter 
where she is-in the mountains, by the ocean, in a busy urban setting, or in her home environment-she works to block any access to the outside world and minimize distractions within her workspace. She says she doesn't care where she works because she doesn't notice things around her. "One wants a room with no view," she argues, "so that imagination can meet memory in the dark."

\section{Vignette 3}

I want him to have a good, long run. I have a full day of writing ahead of me and I always feel better when I know he is sleeping because he is tired, not because he is bored. We arrive at the lake and I unclip his leash. He immediately heads for the water, wades in belly-high plowing the water with his snout, sits for a few seconds, and then jumps up, shakes, and walks back to shore. As always I wish he would swim; as always he keeps mostly to the shore, meandering into the water only for the occasional drink, to cool off with a quick duck, or when he wants to avoid another dog (his version of Nya, nya, nya, nya nya, can't catch me). Instead of the fast-paced, physically challenging workout I have in mind, we inch our way along the shoreline, he with his nose to the ground and I with my eye trained on his movements and ready to offer a sharp, "Drop it". The shoreline is littered; I must be vigilant. I try to interest him in a stick for a game of fetch or chase. He ignores my shenanigans and continues his methodical explorations sniffing, pawing the sand to unearth buried treasure, occasionally picking up something in his mouth and not always dropping it on command. I come across an empty plastic water bottle and give it a kick so that it skims along the sand, an enticement for sure I think. The noise and movement catch his attention. He looks up, satisfies his curiosity, and resumes his exploring. "Come on, play, run, exert yourself," I silently urge.

We continue along the beach at a snail's pace. I have resorted to entertaining myself by kicking the plastic bottle in front of me as I go. We pass a woman throwing sticks into the water and a dog blissfully swimming to retrieve every one. "See that," I say as we amble by, "that's how it's done." And I toss a stick just in case. No response, except for an imagined "Yeah, so." Thirty minutes later we are still 
sauntering along, he relishing the journey, I intent on the destination. My image of a tuckered-out dog sleeping peacefully at my feet while I work fades with each dawdling step. We eventually reach the crumbling remains of a concrete wall that separates two stretches of beach and I decide to turn back rather than climb over to the next accessible part of the shoreline. We reverse direction and continue ever so slowly to make our way back along the beach, I trying to resign myself to the fact that my plan is not to be and he busily picking his way through the flotsam and jetsam along the shore. (The rule about never retracing steps doesn't apply here; there is sufficient new ground to cover to keep the walk interesting and stimulating.)

Ultimately we once again come upon the plastic bottle that I had abandoned an hour earlier. I give it a careless kick and watch it sail several metres through the air. Almost before I can take another step, he bolts forward in hot pursuit, pouncing on the bottle just as it hits the sand. A backward glance in my direction allows him to judge the range between us and assess how much of a threat I am. With the bottle firmly grasped in his mouth, he charges down the beach at full tilt until he is a safe distance away, screeches to a halt, and plops down in the sand facing me, daring me to advance. As I approach, he releases the bottle only long enough to taunt me. His body and mind on high alert, he is ready to flee at the first sign of my impending seizure. As I cross some apparently predetermined line in the sand he grabs the bottle in his mouth and takes off. The chase is on. Round and round he runs in ever widening circles, sand flying, feet pounding, his body extending with the speed and grace of a racehorse. A thing of beauty. One more loop and into the lake he dashes, dropping the bottle at the water's edge. I rush to pick it up and hurl it into the lake; he swims towards it, snatches it from the water, and heads for shore. The game continues. He is ready now; he has found his stride. This is his way.

The work of a thesis is a process, not an event; it is about the journey, not only the destination. And this journey is as much a journey of self-learning and personal transformation as it is an academic exploration. It is about developing one's identity as a researcher and writer, gaining confidence and 
trust in oneself, finding voice. It is a process that takes time. I am reminded here of Stephen Nachmanovitch's lovely analogy of an oyster:

When a grain of grit accidentally slips into an oyster's shell, the oyster encysts it, secreting more and more of a thick, smooth mucus that hardens in microscopic layer after layer over the foreign irritation until it becomes a perfectly smooth, round, hard, shiny thing of beauty. The oyster thereby transforms both the grit and itself into something new...completing the gestalt according to its own oyster nature. (1990, p. 88)

It takes time to make a pearl and, like the oyster, we need to engage in the creation process according to our own nature. We all have different ways of being and doing, different styles of learning and creating. There is no one right way of researching and writing. Striving to follow someone else's system, routine, practice, route will help you eventually reach your destination but it is likely that the journey itself will be void of deep meaning and you will inevitably miss a lot along the way. You need to find your own style and honour it. You need to find your own rhythm and move to it.

\section{Travel Tips}

And now we leap to a fast-paced ending with some travel tips. I leave you to find the dog stories in these points.

1. Research/write what you most want to know. Following your passions will sustain you through a long and arduous journey.

2. Striving for the 'unique' study or 'original' idea is a misdirected goal. Research is a communal act.

3. Take ownership of your work. This is your thesis.

4. Find someone besides yourself who believes in you. The thesis journey is a lonely one.

5. Work in 3D: discipline, determination, and deadlines. Read, read, read. Write, write, write.

6. See and believe in yourself as a researcher and writer. Take your work and role seriously. Dignify them.

7. Make your thesis a priority. 
8. Take time to know who you are and what you and your work stand for. Don't be bullied by those with opposing views.

9. Hours spent talking about writing is time spent not doing it. A thesis is written one word at a time.

10. "The scariest moment is always just before you start" (King, 2000). Start writing NOW ... and KEEP GOING

11. Maintain your focus; stay the course.

12. Be prepared for hard work and dedication to the task. Persistence and determination will take you $90 \%$ of the way.

13. Establish and stick to a disciplined schedule. The longer a project is stretched out the greater the chances of losing interest.

14. In the beginning.... suspend your critic. Write as fast as you can to get it all out, in order to, as Stephen King (2000) would say "outrun your selfdoubt".

15. Be prepared to let go-of preconceptions and expectations, of plans, of that line that took you all day to perfect.

16. Trust and revel in the process.

17. Strive to nourish your body and spirit as well as your mind.

18. Your thesis is only a small piece of your life and career not all of it.

19. Be prepared to end up with more questions than answers.

20. Your relationship with your supervisor or advisor is up there with other significant relationships. At this point in your life and career this relationship matters a lot.

\section{Proverb}

On that note I will conclude with a story, a proverb, that my former supervisor, mentor, and dear colleague, Dave Hunt, recently shared with me. It is particularly apt for today because of its consistency with our animal motif.

\section{The Rabbit's Thesis (Author Unknown)}

One sunny day a rabbit came out of her hole in the ground to enjoy the fine weather. The day was so nice that she became careless and a fox sneaked up behind her and caught her.

"I am going to eat you for lunch!", said the fox.

"Wait!" replied the rabbit, "You should at least wait a few days."

"Oh yeah? Why should I wait?" 
"Well, I am just finishing my thesis on the superiority of rabbits over foxes and wolves."

"Are you crazy? I should eat you right now! Everybody knows that a fox will always win over a rabbit."

"Not really, not according to my research. If you like, you can come into my hole and read it for yourself. If you are not convinced, you can go ahead and have me for lunch."

"You really are crazy!"

But since the fox was curious and had nothing to lose, it went with the rabbit. The fox never came out.

A few days later the rabbit was again taking a break from writing and sure enough, a wolf came out of the bushes and was ready to set upon her.

"Wait!" yelled the rabbit, "you can't eat me right now."

"And why might that be, my furry appetizer?"

"I am almost finished writing my thesis on the superiority of rabbits over foxes and wolves."

The wolf laughed so hard that it almost lost its grip on the rabbit.

"Maybe I shouldn't eat you; you really are sick-in the head. You might have something contagious."

"Come and read it for yourself; you can eat me afterward if you disagree with my conclusions."

So the wolf went down into the rabbit's hole and never came out.

The rabbit finished her thesis and was out celebrating in the local lettuce patch. Another rabbit came along and asked,

"What's up? You seem very happy."

"Yup, I just finished my thesis."

"Congratulations. What's it about?"

"The superiority of rabbits over foxes and wolves.",

"Are you sure? That doesn't sound right."

"Oh yes. Come and read it for yourself."

So together they went down into the rabbit's hole. As they entered, the friend saw the typical graduate abode, albeit a rather messy one after writing a thesis. The computer with the controversial work was in one corner. And to the right there was a pile of fox bones, on the left a pile of wolf bones. And in the middle was a large, well-fed lion. 


\section{The Moral}

The moral of the story: The title of your thesis doesn't matter. The subject doesn't matter. The research doesn't matter. All that matters is who your advisor is.

\section{Thank You}

Thank-you for listening to me and to your dogs and bon voyage.

\section{References}

Berkowitz, P. (2003). The long haul. University Affairs, February, 8-12.

Clothier, S. (2002). Bones would rain from the sky. New York: Warner Books.

Cole, A. L., \& Hunt, D. E. (Eds). (1994). The doctoral thesis journey: Reflections from travellers and guides. Toronto, ON: OISE Press.

Dillard, A. (1989). The writing life. New York: Harper \& Row.

Glesne, C., \& Peshkin, A. (1992). Becoming qualitative researchers. White Plains, NY: Longman.

Goldberg, N. (1986). Writing down the bones: Freeing the writer within. Boston, MA: Shambhala Publications.

Griffin, G. B. (1992) Calling: Essays on teaching in the mother tongue. Pasadena, CA: Trilogy Books.

Heshusius, L. (1994). Freeing ourselves from objectivity: Managing subjectivity or turning toward a participatory mode of consciousness. Educational Researcher, 23(3), 15-22.

King, S. (2000). On writing: A memoir of the craft. New York: Pocket Books. Nachmanovitch, S. (1990). Free play: Improvisation in life and art. New York: Jeremy T. Archer/Putnam.

Steinbeck, J. (1962). Travels with Charley in search of America. New York: The Viking Press. 


\title{
Can Academic Success Come from Five Minutes of Physical Activity?
}

\author{
Julienne K. Maeda \\ University of Hawaii \\ Lynn M. Randall \\ University of New Brunswick
}

\begin{abstract}
Being physically active helps not only in the areas of health and fitness, but also in the area of academics, more specifically, mathematics. Brain-based teaching can play a large role in enhancing student learning through the use of movement, in particular, a short running activity on math fluency in addition problems. Could five minutes of a moderate to vigorous activity have any effect on students' addition fluency? The purpose of this article is to share with readers the effects of infusing a short physical activity into an already busy day. Two primary findings were gleaned from this study. First, although there was a small positive effect on math fluency, there was no negative effect. Second, positive changes in students' behavior were noted by the classroom teacher.
\end{abstract}

\section{Introduction}

After as little as five minutes of a moderate-vigorous physical activity (i.e., running) four days a week, a class of second grade children was able to concentrate more, the teacher was able to complete more activities, math fluency increased, and the daily classroom routines and overall grades of the students were not negatively affected by the running; rather both improved as a result. The purpose of this article is to share with readers the ingredients for infusing a short physical activity into a busy day.

Julienne K. Maeda is an Assistant Professor at the University of Hawaii at Manoa in Honolulu. Lynn M. Randall is an Assistant Professor at the University of New Brunswick in Fredericton. Both have research interests in aspects of elementary physical education, one of which is the balance between physical activity and academic performance. 
Physical inactivity and unhealthy eating contribute to at least 300,000 preventable deaths each year (US Department of Health and Human Services, 2001). Becoming physically active on a regular basis is the key, and the activity need only be moderate in nature to reap benefits. Although regular participation in 30 minutes of intense activities or shorter more vigorous bouts of 15 minutes is suggested per exercise session for adults, such recommendations are different for children. Corbin and Pangrazi (1998) suggested that children accumulate at least 30-60 minutes of age and developmentally appropriate physical activities on all or most days of the week.

Schools provide an ideal place to help improve and develop more healthy habits (DHHS, 2001). Werner, Timms, and Almond (1996) reported that panelists from a news briefing by the American College of Sports Medicine suggested that "schools are the most likely place to change physical activity patterns and that physical education curricula should provide movement experiences that are enjoyable, provide significant amounts of physical activity, and promote lifelong participation in physical activity" (p. 49). Recesses and the time before and after school provide a small portion of time when children can be active. Regular participation in a developmentally appropriate physical education program is another portion of time for physical activity.

Elementary physical education is often children's first formal experience with movement instruction and it is a time where they begin building a foundation of motor skills for later participation in sports and other physical activities. Physically educated students learn the importance of being active, how to be active, and value such a lifestyle (National Association for Sport and Physical Education, 1995). They are students who become knowledgeable physical activity participants and spectators, practice the meaning of teamwork, and are provided the tools to become active, healthy adults. Although participation in physical education is a good source of physical activity and the breadth of benefits extends beyond the physical, it is often not allotted enough time with regard to the development and maintenance of fitness and motor skills. Elementary physical education programs taught by a physical education specialist in many parts of the United States and Canada are typically scheduled once a week per class, or even less as they are in several schools in Hawaii (i.e., once every two weeks). Supplemental days of physical education and/or shorter bouts of physical activity are important and would benefit students.

Historically, physical education has been viewed as a class that reduces instruction time in other content areas. Yet, numerous links have been made between the mind and body (Jensen, 1998) showing how efforts coordinating both can be much more effective. More recently, Sallis, McKenzie, Kolody, Lewis, Marshall, and Rosengard (1999) reported that physical activity levels 
found in elementary physical education classes taught by a specialist may in fact contribute to academic achievement. Spending more time in physical education did not have negative effects on standardized academic achievement test scores in the elementary school children in that study and the thinking that physical activity negatively affects cognitive function is untrue (Sallis et al., 1999).

\section{Movement \& Academics}

"Movement is an indispensable part of learning and thinking" (Summerford, 2001, p. 7). Furthermore, movement can help to reinforce the academic skills of all students (Blaydes, 2001; Jensen, 1998; Sallis, et. al., 1999). Although physical activity and movement do not necessarily make children smarter, they do contribute to how they learn and how much can be learned. According to Hannaford (1995), 85\% of children in school are kinesthetic learners. In other words, these children learn better by moving and interacting with their environment rather than sitting and only receiving information visually or by listening. The belief that movement should only be limited to physical activity in physical education is contrary to what is known as brain-compatible learning. In fact, with the outdated thinking that physical education is a frill, many students are missing the neural benefit movement can have on academics (Summerford, 2001). According to Jensen (2000, 1998), movement and physical education do, in fact, contribute to enhanced brain function.

However, with the increasing pressure and accountability in subject areas such as math and reading, time has become an even more precious commodity. Indeed, although time has become very valuable to teachers, planning as little as five minutes a day of concentrated physical activity could contribute to academic performance and student behavior. The purpose of this article is to share with readers a recipe for infusing physical activity into a busy day. After as little as five minutes of moderate-vigorous activity (i.e., running, walking), the children who participated in this study were able to concentrate more, the teacher reported being able to get more done, math fluency increased, and that fluency was not negatively affected by the physical activity.

\section{Methods \& Procedures}

\section{Participants}

The participants in this study were one second-grade class in an elementary school $(\mathrm{N}=19)$ in Hawaii. There were 7 boys and 12 girls who participated. Of the 19 students, 2 received special education services. 


\section{Procedures}

The teacher of the class divided the students into two groups based on their performance in math related to addition concepts, a) grade level group and b) below grade level group. Three versions (e.g., three sheets per version) of addition problem sheets were used. Three different versions were used to minimize any chance of students memorizing the problems and answers. Each version was used alternately throughout the week. For example, version 1 was used on day 1 , version 2 on day 2, version 3 on day 3 , then back to version 1 on day 4 , etc. Using dry-erase pens and transparency sheets, each student answered as many math problems as they could within one minute upon returning to the classroom after the walk and/or run. The teacher corrected all sheets then cleaned the transparencies.

A timer was used to signal the end of one minute. The use of oneminute timings is a short yet sufficient interval for measuring performance (Binder, Haughton, \& Van Eyk, 1990). The one-minute timings allow teachers and students to easily calculate per minute frequencies and accommodate those who have attention difficulties. Also, such a short period allows for many opportunities for students to respond and improve on fluency and for teachers to make curriculum-based decisions.

Fluency is a factor related to student learning. According to Binder et al. (1990), students must develop certain minimum levels of speed and accuracy on individual curriculum tasks. Fluency in this sense is defined as accurate, non-hesitant performance where work becomes steady for significant durations. Through short timings, where correct responses per minute are recorded, the number of opportunities to respond is high, thus helping to increase and improve fluency.

The weekly routine, approximately an hour after lunch four days a week, consisted of: restroom/water, physical activity, water, and then return to the classroom for the math activity. The walking/running route was near the classroom building or a short distance away (if it rained), and students ran and/ or walked the length of their building (i.e., a building that houses about 10 classrooms) for a period of five minutes. The classroom teacher had used this form of physical activity with previous years' classes and had introduced it to the participants in this study. Since the class was familiar with the route used, they did not need to be familiarized with it for this project. The teacher instructed them on what direction to take (e.g., clockwise direction) then sent them off for the five-minute time. Passing was only allowed after the first lap. On rainy days, the class walked/ran on a good stretch of walkway a short distance from their building. The teacher encouraged all of the children to keep moving throughout the five minutes. 


\section{Design}

Using a multiple treatment reversal design (Cooper, Heron, \& Heward, 1987), several phases depending on the intervention are provided. With this design, each phase served as a baseline for the subsequent phase (Cooper et al., 1987). Therefore, when experimental (i.e., intervention) variables are introduced, their effect is compared to the level of the baseline (i.e., Phase A) and when removed (i.e., subsequent phases other than A), the attempt is to reproduce baseline levels. It is the change in the trend of the data that is being examined via visual analysis through the use of graphs.

\section{Data Analysis}

In single-subject research, data are analyzed using visual analysis of graphs (Cooper et al., 1987). Visual analysis provides the viewer with their own means of interpreting the data and of judging any significance in behavior changes. In this study, Phase A (refer to Figure 1) otherwise known as the baseline, was composed of the one-minute timing of addition problems and no physical activity. A decreasing trend and data path are visible in all three Figures during Phase A. In other words, the number of correct problems per minute decreased during this phase.

Figure 1 - Class Medians

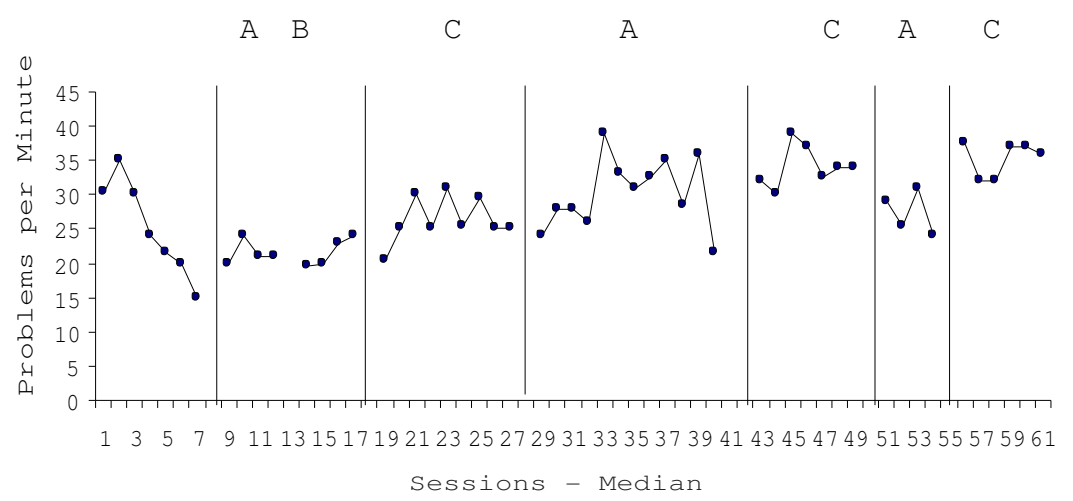

Phase B was the introduction of a physical activity (i.e., running) with the oneminute timing of addition problems immediately afterwards. The teacher reported that the students spent more of the five minutes walking than running. This could be explained by the low fitness level of the students. This study started approximately a little more than one month into a new school year, and in general, students do not tend to be in good physical shape after summer 
vacation. During this phase, the data path was slightly higher and much more stable than in the previous phase. However, since the majority of the students were walking for the five minutes instead of running, it was decided by the researchers to use walking as the next physical activity, hence Phase $\mathrm{C}$. The design of this study allows for changes to be made while the study is taking place to help improve the targeted behavior; any changes become a new phase (Cooper et al., 1987).

In Phase $\mathrm{C}$, students were encouraged to walk briskly for the fiveminute time period. In this phase, the data path increased and the number of addition problems answered correctly by the class increased. Once the data path in Phase $\mathrm{C}$ reach a point of relative stability, Phase A was re-introduced to see if a decrease in performance occurred as a result of no physical activity. In this second Phase A, math fluency seemed to continue at the level of the previous phase. However, after four sessions and a sharp increase in math problems answered correctly, performance again began to decrease. The sharp increase cannot be explained. With Phase $\mathrm{C}$ showing a positive effect when compared to Phase $\mathrm{A}$, Phase $\mathrm{C}$ was introduced again. With the re-introduction of Phase C, the data path returned to a higher level of fluency than Phase A and remained at a relatively high level. To attempt to repeat a return to baseline levels of performance, Phase A was again re-introduced. According to Cooper et al. (1987), a return to baseline levels again strengthens the design and effect of the intervention.

Math fluency in the third introduction of Phase A decreased almost immediately. After four sessions, Phase $\mathrm{C}$ was re-introduced a last time. Math fluency returned to a relatively high level and was clearly better than performance in Phase A. Similar trends in the data between phases can be seen in Figures 2 and 3.

Figure 2 - Grade Level Group Medians

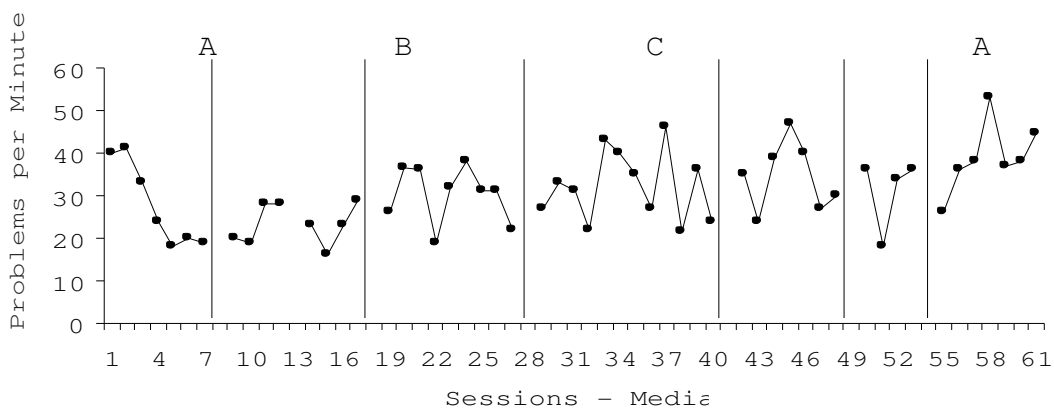


Figure 3 - Below Grade Level Group Medians

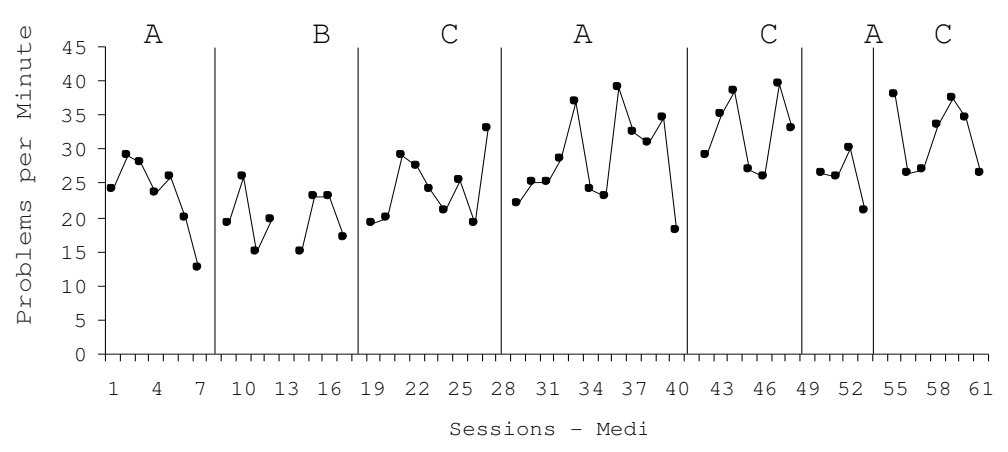

Figures 2 and 3 depict the performances of the two math groups Grade Level and Below Grade Level. Both graphs mirror performance in the class graph; however, the effect of the physical activity appears to be much stronger for the below grade level group than for their grade level peers. The number of problems answered correctly by the below grade level group appeared to be more clearly affected (i.e., higher trend in data path) by the physical activity in Phase $\mathrm{C}$ and in Phase A.

Despite small changes in levels of data paths between phases, it is visible that the physical activity did have some effect. Math fluency of the students on days they did not do any physical activity was drastically different from days when they did. Anecdotal comments from the teacher were interesting and supportive of the physical activity. She reported observing some positive changes in her students' classroom behavior and anxiety levels.

\section{Discussion}

Physical activity does not negatively affect academic performance (Blaydes, 2001; Sallis, et al., 1999). In fact, it can help children to do better. Overall, math fluency improved. However, improvement was not limited to only math fluency. Improvements in the behavior of the whole class after the physical activity were made, and the teacher reported anecdotally that they were able to get more done. She could accomplish her list of the day's activities with some time left for the children to do their homework. However, on days when there was no physical activity, she was not often able to accomplish as much. More time was spent getting the class to settle down and maintain their attention, and 
often the students were not left with any time to even start their homework because they either barely finished their day's activities or did not finish them.

The teacher also reported that the children enjoyed both activities immensely. They often chose not to drink water after the physical activity so they could get started on the math activity. It is very exciting to hear that an entire class of second grade children was very motivated to do a short physical activity. The effect of the physical activity on math fluency and behavior confirmed this teacher's belief that outdoor activity of a physically demanding nature is an important part of every child's day. The children were also so excited to get started on the math activity that the time it took to return to the classroom was minimal. With the math activity taking one minute to complete, it did not take much longer for the teacher to correct. In the whole scheme of things, both activities did not take much time at all. Classroom teachers have many responsibilities; however, improved student behavior after physical activity can make up for any time used outside of class in the amount of work that may be accomplished. These findings are supported by Sallis et al (1999), who reported that physical activity had no negative effect on academic achievement. There is much more to cover relative to academics, but physical activity should not take a back seat to other subject areas when in fact it can enhance performance in those areas (Summerford, 2001).

\section{References}

Binder, C., Haughton, E., \& Van Eyk, D., (1990). Increasing endurance by building fluency: Precision teaching attention span. Teaching Exceptional Children, 22(3), 24-27.

Blaydes, J. (2001). Advocacy: A case for daily quality physical education. Teaching Elementary Physical Education, 12(3), 9-12.

Cooper, J. O., Heron, T. E., \& Heward, W. L. (1987). Applied behavior analysis. New York: Macmillan.

Corbin, C. B, \& Pangrazi R.P. (1998). Physical activity for children. A statement of guidelines. Reston, VA: Council on Physical Education for Children (COPEC) of the National Association for Sport and Physical Education.

Hannaford, C. (1995). Smart moves. Why learning is not all in your head. Arlington, VA: Great Ocean Publishers.

Jensen, E. (1998). Introduction to brain-compatible learning. San Diego, CA: The Brain Store.

Jensen, E. (2000). Brain-based learning. San Diego, CA: The Brain Store. 
National Association for Sport and Physical Education (NASPE). (1995).

Moving into the future: National standards for physical education. St. Louis, MO: Mosby.

Sallis, J. F., McKenzie, T. L., Kolody, B., Lewis, M., Marshall, S., \& Rosengard, P. (1999). Effects of health-related physical education on academic achievement: Project spark. Research Quarterly for Exercise and Sport, 70, 127-134.

Summerford, C. (2001). What is the impact of exercise on brain function for academic learning? Teaching Elementary Physical Education, 12(3), 6-8.

United States Department of Health and Human Services (DHHS). (2001). Physical activity and good nutrition: Essential elements to prevent chronic diseases and obesity (at a glance). Retrieved October 30, 2001, from: http://www.cdc.gov/nccdphp/dnpa/dnpaaag.htm

Werner, P., Timms, S., \& Almond, L. (1996). Health stops: Practical ideas for health-related exercise in preschool and primary classrooms. Young Children, 51(6), 48-55. 


\title{
Forming Social Justice Projects: Student Activists Reflect on Coalition-Building
}

Darren E. Lund

University of Calgary

\begin{abstract}
Student activists share their experiences with racism and more specifically, their attempts to form school diversity initiatives. The author outlines a problematic lack of engagement of student activists in the scholarly literature on social justice, particularly related to their undervalued role as leaders in school-based antiracist coalitions. Excerpts from in-depth interviews with seven student participants in western Canadian schools offer new understandings on the potential of school-based activists. They explain the challenges and successes in building and sustaining activist coalitions and in pursuing their social justice efforts beyond school. Their contributions represent new voices to join the ongoing conversation in educational research and community activism.
\end{abstract}

Never doubt that a small, group of thoughtful, committed citizens can change the world. Indeed, it is the only thing that ever has. (Margaret Mead)

School activists who work to counter discrimination in the context of contemporary public schools face a number of challenges, particularly in light of the current backlash toward diversity initiatives. Seeking a link between the theoretical literature and the lived experience of actual student activists, this study was conducted to understand the workings of school-based initiatives designed to challenge racism and other forms of discrimination. The present study was designed to gain a clearer understanding of the realities of the activist

Darren E. Lund (dlund@ucalgary.ca) is an Assistant Professor in the Faculty of Education at the University of Calgary. His Ph.D. research on social justice activist coalitions was recognized with the AERA 2002 Outstanding Dissertation Award for Division B, Curriculum Studies. 
work of a small number of students in schools in western Canada. Among other research questions, the researcher sought to learn more about how they viewed their own activism as fostering coalition-building beyond their school experiences.

Conducting school research around issues of social justice requires a theoretical stance that seeks intersections across issues of "race," ethnicity, class, gender, sexual orientation, and other elements of social identity (e.g., $\mathrm{Ng}$, 2003). Hall's (1992) recognition of "race" as a social construction acknowledges the racialized context of contemporary schooling. The researcher intentionally positioned this research itself as a vehicle for both evaluating and facilitating social justice activism, and an instrument of community building among school activists. During the data gathering and analysis phases, regular contact between the researcher and participants allowed the reciprocal sharing of readings, resources, and guidance on social justice activism.

The research literature includes relatively few detailed analyses of student social action projects in Canadian schools, aside from anecdotal summaries of a small number of particular programs or activities (e.g., Berlin \& Alladin, 1996; Smith \& Young, 1996). Over nearly two decades of activism, the researcher has been made aware of numerous collective student initiatives in schools across Canada that tackle social justice issues. The lack of academic attention to successful school-based activist programs suggests that their efforts are either undiscovered or undervalued by the research community. In either case, the present study has taken steps to learn more from the students themselves and thereby to illustrate the benefits of a respectful engagement with activists in the educational community.

Students are rarely engaged in meaningful ways in educational research on social justice. Simply including students in discussions, as subjects of research projects, or as informants in surveys, is not a genuine means of engagement. In fact, these approaches may be viewed as cynical strategies by those in power, designed to falsely justify particular programming or policy changes. Another important acknowledgement needs to be made here that meaningful activist work very likely goes on in schools that remains distanced from university researchers' agendas and hence undiscovered.

Eliciting students' equitable participation in studies of social justice pedagogy more appropriately answers the call of other Canadian activists (e.g., Dei, James, James-Wilson, Karumanchery, \& Zine, 2000) to find meaningful ways of engaging them in bringing about change in schools and communities. For all of the inherent challenges, authentic collaborations between researchers and school activists hold tremendous potential for enacting progressive school change toward equity and fairness. The intentional engagement of young 
activists as respected participants in this research acknowledges their significant roles as leaders and valued informants in this area. Further, earlier reports on findings from this study also address what Giroux (1996) has identified as a growing conservative backlash toward "youth" culture in general (see Lund, 2001).

\section{Initial Guiding Assumptions and Hypothesis}

As a long-time activist and educator in this field, the researcher posited that ongoing projects would provide students with agency and a legitimate avenue to address diversity issues, tap into current community concerns, and provide ongoing opportunities for dialogue, debate, and consensus-building among the participants. Exploring a wide range of concerns and issues around specific activities in schools, this study focused on particular expectations, framed as a set of "guiding hypotheses" that Marshall and Rossman (1995) describe as "tools used to generate questions and to search for patterns" (p. 37). One hypothesis was that students' activism in school-based coalitions would lead to further activism and political engagement in their lives outside the school, and that involvement in this research would extend their sharing and networkbuilding. Many of the activists interviewed had already been involved in social issues in their communities for some time before they took on the work of coalition-building in their school settings. Past experiences with forming an activist group early in the researcher's teaching career strongly suggested that activist efforts in schools might further encourage students' long-term commitments to social justice.

\section{Students Engaging in Collaborative Action}

During the researcher's first year of teaching high school in Alberta, a rowdy group of students in a non-academic English class initiated the formation of Students and Teachers Opposing Prejudice (STOP). It has remained a popular school program and has been widely recognized for its innovative approaches to challenging racism and other forms of discrimination (e.g., Alberta Human Rights and Citizenship Commission, 2000; Canadian Race Relations Foundation, 2001). The students were excited when the US activist rock group, "Rage Against the Machine," named the STOP program "Freedom Fighter of the Month" in March, 2000.

STOP was formed in the potentially volatile social context of a region of Canada better known for extremist activity promoting racism (Kinsella, 2001), but has managed to recruit students, teachers, parents, administration, 
other school staff, government, media, and community agencies in a collective undertaking to challenge barriers to social justice. Activities have included awareness campaigns on violence against women, Tibetan independence, environmental concerns in Nigeria, First Nations issues in Canada, the rights of children, and Alberta's human rights policies. Specific student and teacher activism has entailed interrogation of school policies and curriculum materials, presentations to government officials, drama presentations to children, organizing local protests, international human rights advocacy, and public debates with political leaders on government policies (see Lund, 1998).

Over the past 16 years, several former STOP members have won recognition and awards for their exemplary community service and citizenship while working on projects for STOP. Numerous others have graduated to accept positions in international service agencies such as the UN and the Red Cross, with many former student activists continuing their work with human rights groups and social agencies as adults. Some former STOP student activists are engaged in related pursuits including teaching elementary school, nursing, social work, musical benefit concert promotion, and graduate studies in gender issues.

\section{Engaging Students in Collaborative Research}

An intention for the present study, reported in greater detail elsewhere (Lund, 2001) was to interview student activists engaged in social justice and diversity projects in their schools and communities around Alberta. Activists were identified using a "community nomination" method of selection, following the work of Foster (1993). Located through a network of teacher colleagues, professional associations, and community activists, participants in this research included seven students whose length of experience in this field ranged from one to five years. They lived in rural, smaller urban, and large urban settings, and came from a variety of ethnocultural backgrounds, as described briefly below. Their ethnic and geographic locations undoubtedly shape and inform their contributions, both as noted below and in complex ways to be explored in future analysis and research.

Semi-structured interviews took place over a period of about two years, and included site visits and at least two hours of in-depth conversation with each participant; these were tape-recorded, transcribed, and brought back to the participants for validation or revision for accuracy. Few changes were made to the original transcripts besides some minor corrections for clarity and grammatical correctness. Transcripts and other data were coded and analyzed 
for embodied meaning and subjected to validity requirements as outlined by Carspecken (1996).

\section{Participating Student Activists}

Lisa $^{1}$ was in grade 11 at a large Catholic high school in a smaller urban setting in the province. She was not yet active with an organized student club, but was taking steps to form a program to address diversity issues in her school. She and other friends sought permission from their school to promote a community awareness project on diversity. Lisa was white, Catholic, and 16 years old at the time of our interview. She was interviewed in the cafeteria of her school.

Sina is a Muslim of Indo-Canadian background who was in grade 12 in a diverse high school in a large urban centre. She noted that she often faced discrimination based on religious stereotyping, commenting that "when I tell people that I'm Muslim they automatically think that I' $m$ from Arabia and that I'm a terrorist.". She had been active in the school's annual participation in a regional student diversity leadership camp, was President of the school's Student Council, and also tutored non-English speaking students. We spoke at a coffee shop near her high school.

Sabrina and Ramona are sisters who were in grades 10 and 11, respectively, and both were active in their high school in a large urban centre. They were involved in an enriched academic program and both had taken on leadership roles in their school. Of Asian ancestry, they were fluently bilingual and both expected to attend university after graduation from high school. Ramona coordinated the school's Amnesty International chapter for two years. Sabrina was the student leader of another school club that also addresses social justice concerns. Both have also been actively involved in other local organizations that address poverty, human rights, and other social issues. I interviewed them separately in a foyer at the university near their high school.

Daria was in grade 12 in a large and diverse high school in a large urban centre, and identified herself as Latina of South American origins. She was born outside Canada and said her immigrant status shaped her experiences in the area of addressing diversity issues. Together with Steve and Jason, below, she helped form a student action group across three high schools. They met weekly and organized a variety of activities to educate other young people on the benefits of diversity and the dangers of discrimination. We spoke after school and the only available space was in her principal's office. She eagerly took his seat and I interviewed her from a small chair in front of the large desk,

1. All of the names of participants mentioned here are pseudonyms.

2. Readers should note that these interviews took place before the events of September 11, 2001. 
creating an interesting and symbolic rearrangement of the traditional researcher role.

Jason was also in grade 12 but attended a small urban high school. He described himself as a fairly average, mainstream guy. He and two of his friends, Steve and Daria, organized a program to challenge racism and other discrimination. The group received some favourable recognition from the media and a government agency, and at the time of the interviews, was organizing presentations to schools in their region.

Steve was also in grade 12. I interviewed him and Jason after an educational conference at which they had co-presented a session to teachers on taking action against racism with students. Both are of Anglo-Saxon origins, 17 years old at the time of the interviews, and both were in an academic school program with expectations of university attendance following graduation.

\section{Voices from the Student Activists}

For the students who are relatively new to activism, participation in schoolbased social action is gradually becoming an important part of their lives. ${ }^{3}$ Lisa explains that she was initially drawn into social justice activism by the experience of her father's becoming paraplegic in recent years. Watching her father face a number of physical and attitudinal barriers in society has helped to strengthen Lisa's resolve to assist in the struggle for social justice for disadvantaged or marginalized groups. "That happened about five years ago," she says, "and it probably did have something to do with [my interest in this area], because I can see how people treat disabled people differently." She has become sensitized to seeing the world through the eyes of another person who faces serious challenges on a regular basis, and believes this to be a catalyst in her wishing to form a group to fight discrimination of various types.

Lisa's desire to act on her sense of justice began with a strong role model; she admires that, "everywhere we would go, if it isn't wheelchair accessible or there aren't parking spots, my father will go in and just ask all these questions and often ask, 'Don't you people know anything?' and it's just pretty funny. Like we've even gone to the police station and got people ticketed for parking in handicapped spots!" Her admiration of the fighting spirit of her parent has inspired her own wish to take on issues that others in her school might simply ignore.

Even while in junior high school, Lisa had been involved in a "Justice and Peace" group sponsored by one of her teachers, but she expresses

3. The author uses the present tense in this section to enhance the immediacy of the participants' voices. 
disappointment that "we didn't do a lot globally. It was more making breakfasts for the kids-that kind of thing." Her wish to help others was fueled when she learned of antiracist activism taking place in her community that had been organized by some other young people, and she wanted to "kick-start" something similar at her school. So far, the only thing her school had done officially in the area of social justice was in response to a visit from Craig Kielburger, who was promoting his "Free the Children" movement (see Kielburger \& Major, 1998), seeking to liberate young people around the world from sweat shops and other exploitation. Lisa comments that "when Craig Kielburger came, about five students shaved their heads and raised money," but expresses frustration that momentum failed to build after his visit: "I thought there might have been a little bit more inspiration after the kids shaved their heads." She speculates that "maybe if we kind of related that [awareness] into other issues it might raise some awareness." Although her efforts to do so have not yet resulted in the successful formation of a lasting group at her school, she remains interested in social justice issues and in working collectively with others to confront injustice. She says, "For myself, a lot of the women's rights issues interest me, like what's currently going on in Afghanistan and Indonesia. I'm very interested in that personally, but we could probably build up to tackling things like that in our group." Lisa acknowledges another hurdle, namely that her fellow student activists first need to be educated on international issues of gender discrimination of which they are unaware, "because everyone has to know what they're supporting."

When asked if her experiences trying to organize a school-based coalition might lead her to further engagement outside her school, Lisa says that her wish to form a student group to challenge racism and sexism is fueled by a desire to "promote societal change," and that she expects to become a teacher after graduating from high school. She plans to keep these issues in the forefront of her own teaching, and is inspired by a woman she knows who "has taught in Africa; I'm interested in doing that." She anticipates being involved in social justice work somehow as an adult, and remarks that, as a member of the Canadian mainstream culture, "It's really hard to stay motivated. And then something will set you off, you'll see something on the news or you'll read something and you'll be like, 'Oh, I've got to get back to doing that."'

Lisa says she values cooperation in her activism, and wants to communicate directly with other students already in activist school groups. She speculates, "I was thinking if we did a joint thing with STOP or one of the other groups, our students would get an idea of what it's all about, and then we could try to start something here." She says she values the potential for peer influence and the benefits of having young people share ideas together. Her goal is to 
begin with small initiatives in her school, and then "do a little bit of work with students in other schools." Lisa has heard of the STOP group's annual Holocaust Awareness Symposium and says, "I want to be a part of that; I think that's really important."

Building on the successes of other programs seems a sensible way to start, with a greater chance of achieving results in the early stages of a group's formation. This interview allows her to explore some of these partnership ideas aloud, and to start plans to have interested activist students learning directly from each other. Lisa is motivated both by a personal desire to seek justice for oppressed people, and a sense that disturbing international examples of prejudice remind her of the narrow-mindedness she witnesses in her own school and community. Her identity as a member of the dominant culture of a rather homogeneous white community has perhaps played a role in building her confidence to continue with activist efforts in the face of administrative resistance and peer apathy. She seems encouraged by her modest initial efforts and genuinely committed to continuing her activism beyond school.

Sina has already been in contact with student members of STOP through an organized cultural diversity leadership camp they attended together during the previous year. Using the Internet, she and her schoolmates maintain a personal connection with other student activists hundreds of kilometers away: "We've been talking to them. We all chat on-line so we often talk about the stuff we're doing in our schools. The two of us who are in charge talk to them all the time and we get suggestions and stuff."

Some of the student members of STOP have demonstrated a high degree of computer literacy, and regularly design and modify their own web sites, take part in chat groups, and search the Internet for social action information and related contacts. STOP's recent appearance on an internationally known rock group's web site has brought communication from dozens of young people from around the world, who have sought further information and collaboration with our students. Many young activists seem very comfortable with computers and with the medium of cyberspace as additional tools in their collective struggle for social justice.

Other students working in activist groups in this area show themselves to be interested in developing in-school partnerships to help them achieve their goals to promote diversity and challenge racism. Sina talks about some possible links for her new group to explore within her school, recognizing that these kinds of collaborations can begin to forge important links within the school community and build on the strengths of others to move toward common or overlapping goals: 
In our school we have a drama club and the choral people. We've also talked to them and they're interested in talking about STOP and stuff and doing little skits about issues that we would like. Because we don't have any money in [our program] either, we thought maybe we'd charge a dollar and the drama people could do a little skit about it. Then we'd make money and we could give the drama department some and then everyone would be happy.

Sina says she is inspired by her activist work in school and plans to go to university after high school and continue her work in intercultural understanding:

I was thinking I'd go overseas and just help people there, but I don't know exactly how. Maybe I'd teach them English or something, like with the Aga Khan Foundation. I want to join that, and go overseas and help all those people who don't have the opportunities we do. I was thinking of doing that for a couple of years and then coming back and then doing something else, like international development. I'm not sure yet though.

Though her notions of working in less-developed nations are still somewhat broad, Sina seems realistic in her aspirations. She has a specific organization in mind that has had success in setting up educational institutions in a variety of nations. Her interest and experience in her diverse high school is likely to aid her progress toward this goal. Her identity as an Indo-Canadian female has shaped her notions of social justice, as she indicates by her frank discussions of the racism she has faced.

Likewise, Sabrina says, "I'd just really like to still be involved with Amnesty International in the future. They are effective in what they can do, they have a lot of money, and are involved in so many things." Her involvement as a student with the well-organized international human rights group has been brought about because of the activist group she and her sister formed in their high school. She believes her rocky experiences with fund-raising for Amnesty International and planning events that have been less than successful have helped her develop a greater empathy for social causes.

Sabrina explains, "We've had some experience trying to organize something and seen the apathy out there, so we're not likely to turn down another organization that may need our support." As she and her sister, 
Ramona, have found with their own activist work, "Once you see this sort of thing happening you can't really stop and close your eyes and say, 'I don't know about that sort of thing' anymore." And, as others in this field have observed, Ramona notes cynically that, " $80 \%$ of the volunteering is done by the same people. There are some people who volunteer a whole lot, some just a little, and a whole bunch who don't." Their discouragement about the apathy they see in so many of their peers is inevitably filtered by the ongoing nature of their personal experiences as Asian-Canadians living in a predominantly white urban centre. For these two sisters, the issues of racism and social injustice cannot simply be "put on the back burner" for a more convenient time, but remain pressing and lived aspects of their lives in western Canada.

The cooperation that comes from joining others in the same cause can be very rewarding, especially in this field where the issues that arise can be very sensitive and painful at times. Working with like-minded peers can remind activists that they are not alone in the struggle for fairness, and that, sometimes, voices can be better heard when they join together in a chorus (SooHoo, 1995). Ramona expresses her views about the other activist students she has found in her school: "It's nice to be in a group of people who are all active, who all believe the same things, and who are all working toward the same goals. It's very positive."

Daria is a student activist who says she has found her involvement with an educational coalition to challenge discrimination to be an important part of her identity in many ways. She explains that she had already experienced racism since immigrating to Canada from a South American country, and was eager to work against it:

I remember at a very young age, I was seven at the time, that we did experience racism. I remember walking with my dad back to the home where we were staying and there were I think a couple of teenagers pointing and laughing and saying "Indian, Indian" and I know that there is quite a lot of discrimination against the Aboriginal people, and so we were mistaken as Aboriginal people with our dark hair. My father is dark-skinned and so are my two brothers, and my dad even told us that two blocks from our home there was a man who used to hang a Nazi flag on his window. So growing up in that racist-I'm not going to call the whole community racistbut in a community with people who were racist made it a real personal issue for me. 
Daria says that, in the years since this difficult time, she has not seen racism against her family disappear, even as they learned English and attempted to assimilate into mainstream Canadian society:

Even now, here in [a large city], my mother has a hard time finding a job. She has two degrees in nursing and got one of the highest scores in the [English proficiency] exam in the year that she wrote it. Yet when she was interviewed for a position in nursing, she was told that she would have to go and take an English course. They said that they felt that her accent would interfere with her ability to perform the job well. And I thought that that, in itself, was quite racist, seeing as how my mom does speak fluent English. She does have an accent as do many other people in the nursing field and that does not disable them from performing their jobs.

It is significant that she names such discrimination against people who speak with an accent as "racist," substantially dependent on the skin colour of the person with the accent. Daria also makes a direct link between her family's personal experiences with racism and her own enthusiasm for challenging it in an activist coalition with other young people:

Within my family there has been a lot of experience with racism, so it's a personal issue for me. That's why I think I've been able to stick with it, and to want to keep active. I'm pretty passionate about it, and when I read something in the [newspaper], whether it be anti-Semitism or a racist incident, blatant or even subtle, I take it too hard and I want people to hear about it.

Daria believes that her personal experience with racism both stimulates her interest and provides a distinct advantage to her when speaking to others about the topic:

I think when you experience something and it has degraded you in some way, speaking from experience, that you can relate to victims of racism better than someone who has not experienced racism. It's easier to connect with the crowd when you share your experiences. I also think that just the 
fact that you want to prevent another person from going through what you went through, that's a big driving force.

Her involvement with the activist group has, in turn, encouraged her in many ways to continue to cooperate with other young people in the struggle to eliminate racism and other forms of discrimination. She has reaped several benefits, including becoming a person who is more likely to challenge her own prejudices. She explains:

What I do to try to fight that within myself, especially because I am in an antiracist organization, is that, in order to be a good example to others in the position I'm in now, in order to fight these prejudices with myself, I try to interact with groups that I feel I may have a prejudice against. Whether it be someone who dresses up as a "goth" or someone who is Lebanese, for example, I think that's a way of fighting these internal feelings of racism or prejudice that we may have. When you try to develop understanding and compassion towards a certain group then you begin to eliminate fear and ignorance.

As she has shown in other parts of the interview, Daria does not naively believe that her personal attitudes are the only-nor the most damagingform of racism in Canada, but she targets her own behaviour and values as an important starting point for becoming sensitized and working against all racism.

When asked about the future of her group, Daria is optimistic that its individual members have enough commitment to continue their work in the coming years even if the group comes apart as its members go off to various post-secondary institutions. She believes that high school graduation will likely be a "big blow" to the group but by no means the end of it:

The upside is that perhaps we could all go off to different provinces or different countries and start our own [activist group] within that community. Knowing how committed the members are, and how passionate we've grown to be towards the issue, I don't think that it will fall apart. We need to make sure that we have a huge discussion about this and plan.

Not content to leave things to chance, Daria and her colleagues will be taking proactive steps to ensure that they each continue the work they have begun in their voluntary coalition. 
Setting a strong example for her peers, Daria is already planning to pursue a medical career and join Doctors Without Borders, to "incorporate medicine with social activism." She brings it back to her high school activist work once again: "Just being involved with [our activist group] and doing the humanitarian work has inspired me to pursue that for a job." She seems certain of her continued desire to struggle for social justice, in yet another example of the youthful optimism that fuels this endeavour. Further, her self-identification as a non-white Canadian also seems to drive Daria's single-minded commitment to a career that includes social justice activism.

Steve and Jason share with me that they are often approached by community groups to collaborate on projects, but they are reluctant to be "taken under the wing" of a larger organization, preferring instead to be members of an independent, student-led group. Jason says that, "right now we have lots of contacts with people who are more than willing to give us resources." When I ask for an example, Jason shares that a new antiracist group in their city "has just offered our group some money" but that their student group will need more information about how it fits with their own goals before accepting it. Steve concedes that their group is "still very young and we're still trying to find our way, and this whole government funding thing, you know, we're cautious." Their independence and caution regarding their group's access to resources may be tied to their identity as white males. Although they do not say so directly, their leadership roles in the group provide strategic advantages based on their positions of gendered and racialized privilege. Of course, generalizing about all white people is dangerous and counterproductive to the goals of social justice pedagogy; as Kincheloe and Steinberg (2000) remind us, "it is not contradictory to argue that whiteness is a marker of privilege but all white people are not able to take advantage of that privilege" (p. 182).

Not every student who engages in social justice activism in high school will continue with these pursuits in future. Many students do not consider their high school activist experience as a springboard for future careers and advantages. Steve explains that, "for a lot of us, it's something we want to do because we want to do it now. It's not something that we want to use as a jumping point to any other fields." In fact, says Jason, after graduating high school, "If I had absolutely no ties to bind me, I'd go to the coast and jump on an oil ship and go wherever the winds take me!" Nonetheless, they note that several of their current group members are interested in careers in politics, with at least one wanting to be an international ambassador, and that their involvement with the group will inevitably provide them with some advantages in pursuing these goals. No doubt their identity markers of privilege have also shown them in both subtle and overt ways that they need not worry too much about their own future employment opportunities in this country. 


\section{Conclusion}

As the researcher has experienced with other student activists, and these respondents have corroborated, students engaged in school coalitions seem likely to extend their engagement with social justice issues beyond their school's walls. Their development of crucial cooperative and planning skills, their learning about complex diversity issues, and their experience with organizing a range of activities to promote social justice may all serve to foster further activism. Their differential experiences with racism and other discrimination also play a role in shaping each of their perspectives on social justice work.

Both Jason and Steve reveal evidence of strong success in coalitionbuilding among their peers, and in accessing the kinds of government and community resources their group might need in fulfilling its goals. Their lighthearted notions of commitment to social justice activism, and their confidence in finding support for their work and future employment, are probably fostered to a large extent by their unspoken, learned privilege as white males in an inequitable society. The ongoing project of understanding and dismantling white privilege continues, informed by recent scholarship (e.g., Rodriquez \& Villaverde, 2000). Also, the more limited offerings on this topic in general by these male participants are worth noting here. With their female counterparts more willing to explore issues of collaboration and cooperation toward overlapping goals, this research suggests that the gendered nature of social justice work offers a rich possible field for further inquiry.

In a related example, Sabrina and her sister Ramona both sought the solidarity of their like-minded peers in the face of widespread apathy in their school on issues of human rights. Their establishing of volunteer activist groups provided them with a meaningful way of finding solidarity on issues of social justice, and building on the foundation of other established groups such as Amnesty International. Similarly, Sina found her engagement with fellow high school students at a provincial youth leadership camp helped her establish links among committed school activists. They used the Internet and other computer pathways with great ease to establish an informal network of students interested in promoting diversity and challenging racism, and thus demonstrated that young activists have much to contribute to our growing understanding of the myriad possibilities for networking across diverse groups and communities.

Sina also sought links with established clubs and programs already

existing in her school. Like our STOP program and other groups with whom we have worked, this networking with existing school bodies provides important solidarity in the school-wide efforts toward progressive social change. Sina 
also planned to further her education after high school both through formal post-secondary education and travel, and wished to work toward international development. Likewise, Daria had already planned an ambitious medical career that would combine her interests in social justice and medicine, namely by joining Doctors Without Borders.

The strong notions of future commitment to equity in the careers and community activism of these particular young women have been shaped by their socially ascribed roles as members of non-white ethnic groups in Canada; the discrepancy between their definite goals and those expressed by the young white males in this study suggests a promising direction for further research and analysis. Further, critical educators must continue the struggle to help white students understand the complexities of privilege, unlearn racism, and collaboratively "develop antiracist policies and progressive ways of being white" (Kincheloe \& Steinberg, 2000, p. 194).

Inevitably, the building of bridges among activists and activist groups goes beyond the school walls. As Fullan (1999) reminds us, "by extending purposeful alliances to diverse outside partners we gain moral meaning in educational reform and contribute to its spread" (p. 60). The activist coalitions that form in schools are another vehicle for those already committed to these issues, but for many others, they provide a valuable jumping-off point for a lifelong commitment to fairness and equity. Educators and educational researchers alike need to consider effective ways of working collaboratively and respectfully with school activists to better understand and sustain meaningful opportunities for social change.

The rich offerings from the student participants in this research provide another chorus of voices that can complement those already being heard in academic research and theorizing. Views on their struggles and successes, and other insights from these young activists on working cooperatively in school projects, offer abundant evidence of their previously undervalued role as crucial participants in educational programming for diversity, school reform efforts, and research toward social justice.

\section{Author's Note}

The author gratefully acknowledges research funding for this study from the Social Sciences and Humanities Research Council, the Alberta Teachers' Association, and the Killam Trusts. 
D. E. Lund

\section{References}

Alberta Human Rights and Citizenship Commission. (2000, May). Tools for transformation: Human rights education and diversity initiatives in Alberta. Edmonton, AB: Government of Alberta.

Berlin, M. L., \& Alladin, M. I. (1996). The Kipling Collegiate Institute story: Towards positive race relations in the school. In M. I. Alladin (Ed.), Racism in Canadian schools (pp. 131-146). Toronto, ON: Harcourt Brace.

Canadian Race Relations Foundation. (2001). CRRF 2001 Best practices reader. Toronto, ON: Author.

Carspecken, P. F. (1996). Critical ethnography in educational research: A theoretical and practical guide. New York: Routledge.

Dei, G. J. S., James, I. M., James-Wilson, S., Karumanchery, L. L., \& Zine, J. (2000). Removing the margins: The challenges and possibilities of inclusive schooling. Toronto, ON: Canadian Scholars' Press.

Foster, M. (1993). Self-portraits of Black teachers: Narratives of individual and collective struggle against racism. In D. McLaughlin \& W. G. Tierney (Eds.), Naming silenced lives: Personal narratives and the process of educational change (pp. 155-175). New York: Routledge.

Fullan, M. (1999). Change forces: The sequel. Philadelphia, PA: Falmer Press.

Giroux, H. A. (1996). Fugitive cultures: Race, violence, and youth. New York: Routledge.

Hall, S. (1992). New ethnicities. In J. Donald \& A. Rattansi (Eds.), 'Race', culture, and difference (pp. 252-259). London, UK: Sage.

Kielburger, C., \& Major, K. (1998). Free the children. Toronto, ON: McClelland \& Stewart.

Kincheloe, J. L., \& Steinberg, S. R. (2000). Constructing a pedagogy of whiteness for angry white students. In N. M. Rodriquez \& L. E. Villaverde (Eds.), Dismantling white privilege: Pedagogy, politics, and whiteness (pp. 178-194). New York: Peter Lang.

Kinsella, W. (2001). Web of hate: Inside Canada's far right network ( $2^{\text {nd }}$ ed.). Toronto, ON: Harper Collins.

Lund, D. E. (1998). Social justice activism in a conservative climate: Students and teachers challenging discrimination in Alberta. Our Schools/Our Selves, 9(4), 24-38.

Lund, D. E. (2001). Social justice pedagogy and teacher-student activism: A collaborative study of school-based projects. Unpublished doctoral dissertation, University of British Columbia, Vancouver, B.C. 
Lund, D. E. (in press). Rising to the challenge: Student antiracist activists counter backlash and stereotyping. Teaching Education Journal.

Marshall, C., \& Rossman, G. B. (1995). Designing qualitative research (2nd ed.). Thousand Oaks, CA: Sage.

$\mathrm{Ng}$, R. (2003). Toward an integrative approach to equity in education. In P. P. Trifonas (Ed.), Pedagogies of difference: Rethinking education for social change (pp. 206-219). New York: Routledge Falmer.

Rodriquez, N. M., \& Villaverde, L. E. (Eds.). (2000). Dismantling white privilege: Pedagogy, politics, and whiteness. New York: Peter Lang.

Smith, J., \& Young, J. (1996). Building an anti-racist school: The story of Victor Magel School. In K. A. McLeod (Ed.), Multicultural education: The state of the art national study, Report \#4 (pp. 57-66). Winnipeg, MB: Canadian Association of Second Language Teachers.

SooHoo, S. (1995). Emerging student and teacher voices: A syncopated rhythm in public education. In B. Kanpol \& P. McLaren (Eds.), Critical multiculturalism: Uncommon voices in a common struggle (pp. 217234). Westport, CT: Bergin \& Garvey. 


\title{
Reflection as a Strategy for Teaching Performance-Based Assessment
}

\author{
Moira A. Fallon \\ State University of New York-College at Brockport \\ Susan C. Brown \\ University of Central Florida \\ Blaine C. Ackley \\ University of Portland
}

\begin{abstract}
Educational reform has provided an impetus for teachers to use more authentic assessment in the classroom, having students demonstrate understanding or knowledge through the performance of tasks or skills. Performance-based assessment (PBA) is a concept that inservice teachers and preservice teachers themselves need to understand and use. In this study the authors identify one critical component for PBA participants, that of self-evaluation using the reflective process. Results show that the process of self-evaluation using reflection is critical to concrete aspects of PBA and has implications for schools, teachers, and students. Several self-reflective activities are presented and qualitative findings are discussed.
\end{abstract}

Educational reform has directed a number of initiatives for teachers to use authentic assessment in the K-12 classrooms. These initiatives have caused teachers to rethink their assessment practice and how it relates to instruction (Marzano \& Kendall, 1996). The result has been the growing classroom use of a more authentic assessment in which students demonstrate understanding or knowledge through the performance of skills. Many teachers feel that this type of assessment requires students to apply their knowledge and skills to solve realistic problems that they will encounter in real life (Tombari \& Borach, 1999). The result has been the incorporation of authentic assessment in the public schools (Diamond, 1998).

Authentic assessment, or performance-based assessment (PBA) as it is known in some states, is a concept with accompanying skills that teachers are scrambling to understand and apply themselves before using PBA with their

Moira Fallon is an Associate Professor at the State University of New York-College at Brockport. Her area of specialization is childhood special education. Susan Brown is an Assistant Professor at the University of Central Florida where she teaches classes in cultural diversity and human development. Blaine Ackley is an Associate Professor at the University of Portland with an expertise in assessment and secondary education. 
own students. As school district leaders restructure their curricula, they must ensure that their teachers are trained in the assessment of learner goals or standards using appropriate PBA tasks and accompanying scoring guides (Burke, 1994). In addition, teachers must be able to work with their own students in helping them set criteria and then assess their own performances according to the criteria (Gregory, Cameron, \& Davies, 1997). The problem is that teacher education institutions need to be prepared to create courses about PBA knowledge and skills or school districts need to create in-depth workshops that do the same.

However, navigating the journey of understanding and applying PBA techniques in school settings require that teachers themselves reach a destination of ownership and reflective voice. The constructivist approach to learning is founded on this idea that the learners create new meaning by connecting what they have already learned and experienced with what they are currently learning (Bacon \& Bloom, 1995; McLaughlin \& Vogt, 1996). According to Schon $(1983,1987)$, such self-reflection is central to making meaning of any learning experience. Knowing this, the question was developed: How can we use self-reflection to equip teachers with the skills they need to design PBA that can be used as either part of their assessment of instruction or in high stakes testing?

For self-development as teachers, individuals need to reflect on their teaching-learning experiences while they occur (reflection-in-action) and after they have occurred (reflection-on-action). They then must form theoretical framework related to the experiences, making adjustments in their understanding and subsequent behavior. Killion and Todnem (1991) extend Schon's concept with reflection-for-action, using reflection to anticipate future experiences and their possible consequences. In fact, some researchers recognize reflection as a switch in the mind's operation. As the mind monitors an action, in the very midst of this action, the mind switches to reflection and begins to wonder what is happening (Long, 1999).

The focus of this paper is on self-evaluation using the reflective process, which the authors consider a critical component for any course or indepth workshop about PBA. We collaboratively designed a PBA course with self-reflection embedded as a critical element. The foundation of the course was a strand of self-reflection that linked the very real, and sometimes messy, use of knowledge in the act of performance. This self-reflection process comes directly from the research literature on the self-evaluation process using reflection. According to O'Laughlin (as cited in Bacon \& Bloom, 1995), the fundamental shift in the paradigm mentioned above, and perhaps the ultimate challenge, is to offer learning opportunities that allow the PBA participants to experience ownership of their own learning and to discover the reflective voices that allow them to express their thoughts and experiences. 
It is for these reasons that we embedded within our course an entire strand on self-reflection. The strand included such evaluative activities as keeping a journal on concepts mastered, engaging in dialogue with reflective feedback of peer editors, tracking individual progress towards professional goals, and mapping the evolution of thought processes.

\section{Question}

This study of PBA using reflection was an exploratory one. Specifically, the authors were interested in finding whether a self-reflection strand embedded into a course on PBA for inservice level K-12 teachers would result in more effective learning about PBA and deeper understanding of the assessment issues in designing PBA tasks and accompanying scoring guides.

\section{Implementing the Process}

All participants were enrolled in M.Ed. programs through the same university (although the sites were different), and all were experienced teachers. The oneweek, two-credit course was offered several times during a two-year period.

\section{The Framework}

The framework for the one-week PBA course was that each participant must design and implement a PBA task and scoring guide for use in their own K-12 classroom setting. The PBA task must be based on district standards and curriculum. We also considered the importance of grounding theory in practice by having the participants plan for their own classrooms. The participants were led through the design part of the course using direct instruction, questioning, group discussion, and simulations. We deliberately chose tools and assignments that were open-ended and involved participants as both teachers and learners. Participants were then paired with one another, across content areas and grade levels, to act as peer editors and evaluators.

The authors collaborated to develop the reflective tools and assignments for the strand, using our understanding of self-reflection as a process and our recognition that any PBA must include self-reflection as a component. Throughout the course, we used a spiraling cycle of planning, action, and revision to guide the self-reflection process for the teachers' learning of PBA knowledge and skills. We felt that the continuous use of deliberate reflection would lead to deeper understanding of the assessment issues involved in PBA for both the participants and their students. For us, this self-reflection strand was a key mechanism for developing the reflection-inaction type of critical analysis. 


\section{Self-Reflection Strand Activities}

The self-reflection strand is composed of four reflection tools. One of the tools is used at both the beginning and end of the course. The others are developed for use throughout the PBA learning at designated intervals. The first reflection tool is the "Professional Action Plan" (see Figure 1). At the beginning of the PBA course, the participants are asked to set personal goals for their learning. The goals are updated throughout the PBA course. This goal setting means that participants will individualize the instruction they receive to their own needs and the needs of their students. Prior to the start of the course, the participants are asked to complete the following phrase, "At the beginning of this assessment course, I believe that performance assessment is ..." At the end of the course, participants are asked to revisit the same phrase, without seeing their initial effort. They are then given the first draft and allowed to compare the two definitions of PBA.

Figure 1 - Professional Action Plan

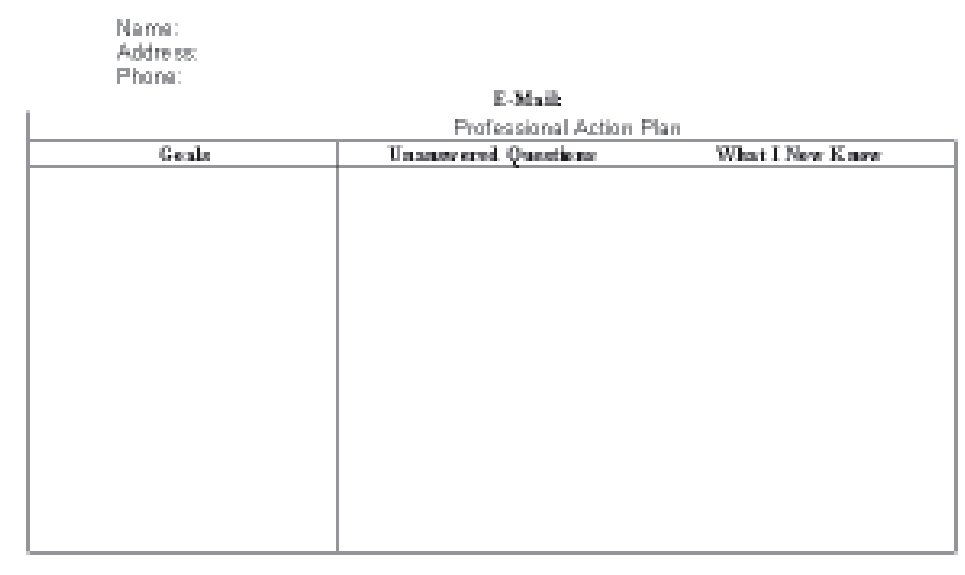

Another self-reflection tool is the "Learning Log" (see Figure 2). This reflective tool requires the participants to track their own insights into the PBA learning process. At designated intervals throughout the course, participants are guided to complete entries in their learning logs. Participants need to be given time to write in the learning logs a minimum of once a day. The logs can also be used to track what these insights mean to their practices in assessment and to their students' performances. 
Figure 2 - Learning Log

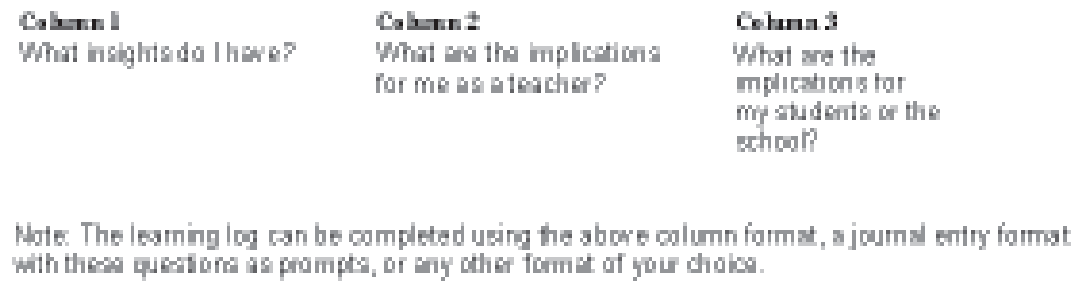

Note. The learning log can be completed using the above column format, a joumal entry format with thesa quesiofa as prompts, of any other format of your chaios.

A final reflective tool is the use of the "Emerging Theory of Action Map" (see Figure 3). In this reflection exercise, participants map their questions, insights, key points, and their emerging model of teacher practices. This tool is used at the end of the course. In it, participants are asked to go back through the course and to map their reflective process in a summary fashion. The other reflective tools may be used to help guide this final product.

Figure 3 - Emerging Theory of Action Map

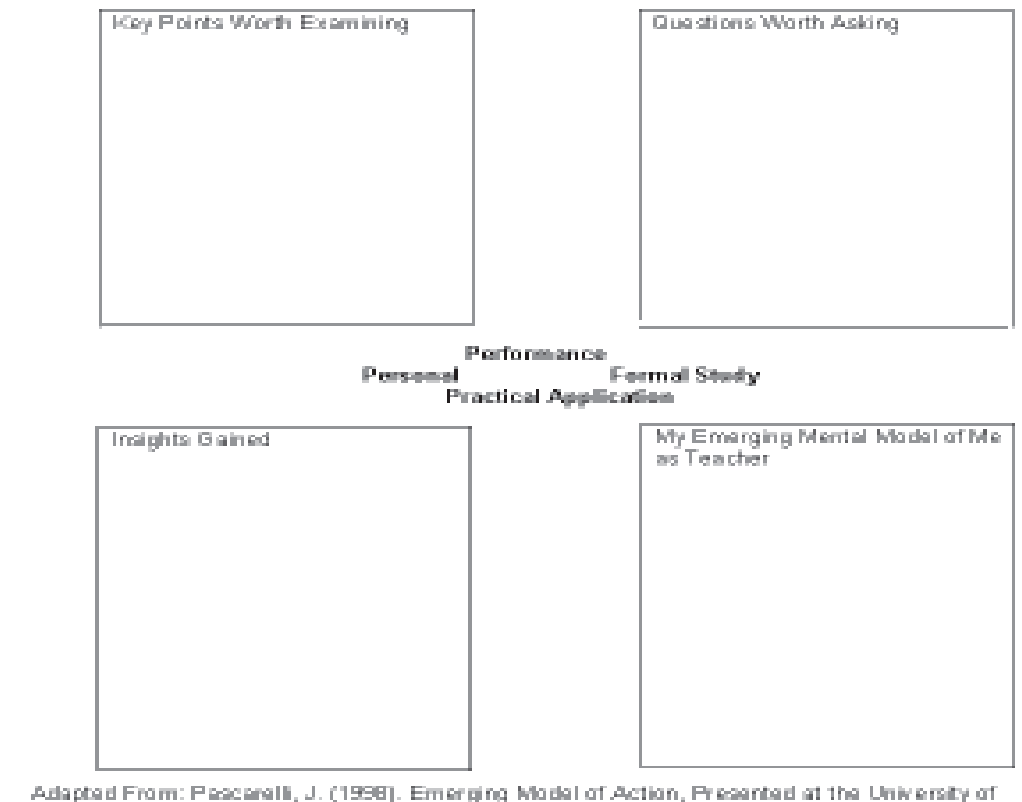




\begin{abstract}
Method
The findings consist of a pre- and post-test of PBA knowledge and concepts and qualitative data on participants' self-evaluation of their reflections as they progressed through a one-week, two-credit course on PBA. The participants reflected upon their knowledge of PBA and their applications on these concepts as they developed a PBA for their individual K-12 classroom settings. The data were gathered over a two-year period of time. The participants $(\mathrm{N}=39)$ included experienced in-service level teachers in the United States, Canada, and Guam, who worked in both public and private school settings.

In order to make sense of the overwhelming amount of data we were able to gather, we reviewed participants' pre- and post test scores on knowledge and attitudes towards PBA, daily reflections, learning logs, professional action plans, and theories of action. For purposes of this study, we computed descriptive data and qualitative themes and patterns from participants' responses. We then selected quotations from participants that represented the themes and patterns we were able to discern (Eisner, 1998; Miles \& Huberman, 1994).
\end{abstract}

\title{
Findings
}

The findings consisted of quantitative analysis on the pre- and post test of participants' knowledge of and attitudes towards PBA, qualitative data on the participants' self-evaluation of their reflections, and descriptive data of the PBA tasks and scoring guides developed by the participants. The results of the paired samples $\mathrm{t}$ test $(t=35.06, p<.0001)$ showed a significant, positive difference in scores from the pre-test to the post test on knowledge about and attitudes towards PBA. The reflection tools used in the gathering the qualitative data were the Learning Logs, the Professional Action Plans, and the Emerging Theory of Action Maps.

The professional action plan assisted the participants in setting goals, tracking unanswered questions, and reflecting upon what they had learned. A summary of response in goal setting is found in Table 1. Seventy-three percent of the participants set goals that were very specific in nature regarding the PBA process. These goals included understanding and using PBA terminology, writing a PBA task that evaluates achievement targets, learning about the specific aspects of PBA, and becoming more effective evaluators. One participant responded, "One of the goals I would like to accomplish ... is to develop and use forms of assessment that truly reflect a child's learning growth." Others said, "...to write clear directions for my PBA" or "To create a 
PBA I will actually use in my class." The unanswered questions that participants worked to answer during the course timeframe included, "Is this the best form of assessment?" or "What things should I be looking for?" and "Where do I find more examples of successful tasks?" Ninety-three percent of the participants achieved their initial goals in the course. However, the majority of these teachers stated that they had replaced the goals with new and more complex ones. Many of them felt they needed to access more resources, to network, and to continue building their skills in the PBA process.

Table 1 - Summary of Responses on Goal Setting Contained in Professional Action Plan

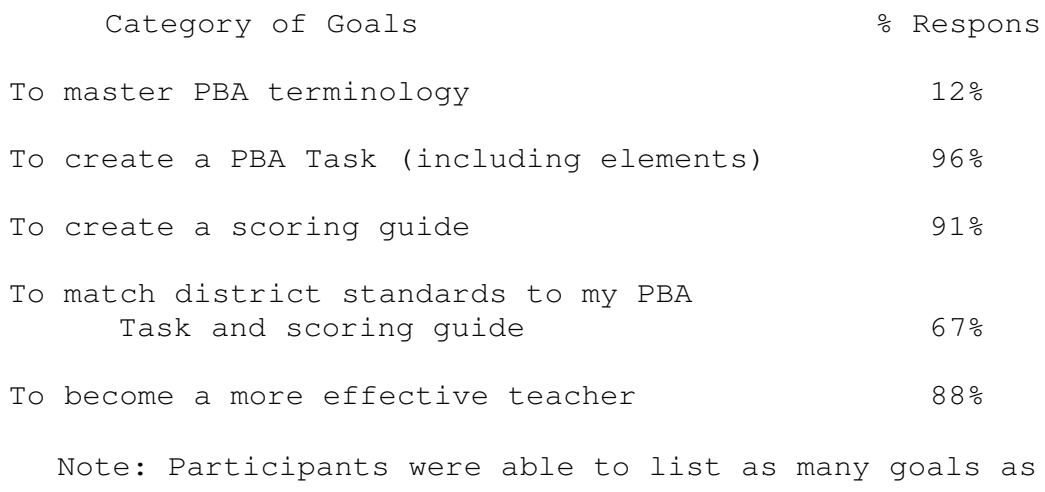

The learning log entries provided a rich source of data on the process of learning about PBA. A majority of participants (68\%) commented on the reflective process using feedback from others in the class. "I learned a lot about clarity and explicitness." "We had to keep in mind that the activity needs to be authentic, engaging, and unusual. The group evaluators helped us identify our weaknesses." "I learned the absolute importance of explicit planning." Many of the entries focused on typical frustrations for teachers, such as, "We tend to focus on the mastery of skills in our students rather than how students will use these skills." or "How do we train parents that there is a better form of assessment?" "Growing up as a student I always thought assessment was paper and pencil, but I have learned it goes beyond that." Another participant said, "I did not find PBA to be as easy as I had assumed. I have to admit I underestimated this project." In answering the question, "Are there implications for my school or students?" seventy-three percent of the participants said it had a strong or important role in how they viewed themselves as a teacher. One participant said, "It has allowed me to look at my 
teaching style and to carefully develop tasks so students can meet any level of objective or standard."

Of the thirty-nine participants in this study, five were unable to develop an emerging model of themselves as a teacher using the PBA process of reflection. Eighty-seven percent $(\mathrm{N}=34)$ did develop that emerging model within the course timeframe. "I see myself more as a coach providing information to my students as the PBA process develops over time." "Incorporating and challenging myself to include culture and to think about adaptations for disabilities." Of the insights into PBA gained by the participants, one said, "Creating good PBA's can be frustrating!" while another commented, "PBA takes more time to create, but students can use them to express more of their learning." One participant said, "Keep revising!" Twelve participants remarked on the ability of the PBA to provide more standardsbased information on students' learning. Seventy-three percent of the participants felt that they were better able to assess individual levels of achievement in diverse learners using a PBA rather than the typical paper and pencil test.

As part of the course, participants designed a PBA task and scoring rubric for use in their K-12 classroom. At the end of the PBA course, these task and rubrics were submitted to a panel of two regional experts on PBA. Each expert independently rated the PBA tasks and scoring guides on a scale of one to five. Seventy-eight percent of the participants received a score of five on the PBA task and scoring guide, while eighteen percent received a rating of four. Four percent of the participants received a rating of three. The inter-rater reliability of the experts was calculated to be .9231 . Each participant received, along with the course grade, a comprehensive written summary of the strengths and weaknesses of the PBA tasks and rubrics. Participants were asked to incorporate the suggested changes before implementing the PBA into the K-12 classroom setting. Thirty eight participants did implement their PBA into their own classroom setting.

\section{Discussion}

As teacher educators, we advocate the use of reflection to enhance the quality of our teacher preparation. We began this exploratory project with an idea for training participants on PBA task and scoring guide. We believe the findings suggest a real need for a comprehensive model that can serve as an integral guide to training PBA evaluators. The results of this project strongly suggest that there is a real need for such a model of helping educators to develop PBA 
and accompanying scoring guides using a strong self-reflection strand as an integral part of the course curriculum.

The participants in this project found that their learning was improved when reflection was integrated into the process of learning to design performance-based assessment tasks and rubrics. We planned for teachers to move beyond simply gaining new technical skills of PBA into a phase of richer understanding of the implications of their practice, both for themselves and their students. We believe that a short, "cookbook recipe" approach to teaching PBA is insufficient. Oversimplification of such a complex learning experience leaves participants with only a superficial knowledge of the development of authentic assessments.

Assessment is more than testing and measurement is more than getting the right answer. The constructivist approach requires that learners connect new learning to the old using learning opportunities that are fostered by their ownership of the process. Such an approach is likened to a kind of puzzlement in which neither the goal nor the means to the goal are stable (Long, 1999); the active experience is the basis for learning, and reflection upon that experience is the active transaction between the learner and the environment. Therefore, in this study, teachers found that discrimination and judgment developed their understanding of PBA, and were in turn enhanced by self-reflection. This is possible only in the real and sometimes messy use of knowledge in the context of the performance itself.

So where do we go from here? If constructivist theory holds true, teachers need to self-reflect regularly so that they become adept at monitoring, assessing, and improving their practice and understanding by discovering their voice and reflecting on their thoughts and experiences (Wiggins \& McTighe, 1998). We believe that the findings of this project may be useful to others in several ways. One way is to incorporate self-evaluation using reflection in other complex learning processes. Another is to adapt the reflection activities to other programs. In understanding such complex issues as PBA, teachers must make meanings of ideas, rather than just using explanations from others in a non-reflective, technical manner. We hope that continued use of the reflective process during such a course will guide participants into continued awareness of their own strengths and shortcomings, thus enhancing their abilities in their own classroom settings. 
Performance-Based Assessment

\section{References}

Bacon, E. H., \& Bloom, L. A. (1995). Beyond the herring sandwich phenomenon: A holistic constructivist approach to teacher education. Journal of Learning Disabilities, 28(10), 636-645.

Burke, K. (1994). The mindful school: How to assess authentic learning (Revised ed.). Arlington Heights, IL: IRI/SkyLight and Publishing, Inc.

Diamond, R. M. (1998). Designing and assessing courses and curricula. San Francisco: Jossey-Bass.

Eisner, E. (1998). The enlightened eye: Qualitative inquiry and the enhancement of educational practice. Upper Saddle River, NJ: Prentice Hall.

Gregory, K., Cameron, C., \& Davies, A., (1997). Setting and using criteria. Merville, BC: Connections Publishing.

Killion, J., \& Todnem, G. (1991). A process for personal theory building. Educational Leadership, 48(6), 14-16.

Long, F. (1999). On teaching reflection. Unpublished paper presented at the biennial conference of International Study Association on Teachers and Teaching, Dublin, Ireland.

Marzano, R. J., \& Kendall, J. S. (1996). A comprehensive guide to designing standards-based districts, schools, and classroom. Alexandria, VA: Association for Supervision and Curriculum Development.

McLaughlin, M., \& Vogt, M. E. (1996). Portfolios in teacher education. Newark, DE: International Reading Association.

Miles, M. B., \& Huberman, A. M. (1994). Qualitative data analysis: An expanded sourcebook ( $2^{\text {nd }}$ ed.). Thousand Oaks, CA: Sage Publications.

Pascareli, J. (1998). Emerging model of action. Paper presented at the University of Portland, Portland, OR.

Schon, D. (1983). The reflective practitioner: How professionals think in action. NY: Basic Books.

Schon, D. (1987). Educating the reflective practitioner: Toward a new design for teaching and learning in the professions. San Francisco: JosseyBass.

Tombari, M., \& Borach, G. (1999). Authentic assessment in the classroom: Applications and practice. Upper Saddle River, NJ: Prentice Hall.

Wiggins, G., \& McTighe, J. (1998). Understanding by design. Alexandria, VA: Association for Supervision and Curriculum Development. 


\title{
Reframing Public Educational Services and Programs as Tradable Commodities - A Synthesis and Critique of British Columbia's Bill 34
}

\author{
Gérald Fallon \\ University of Western Ontario \\ Sonya Pancucci \\ Brock University
}

\begin{abstract}
This paper is a critical analysis of British Columbia's controversial Part 6.1 of the School Amendment Act 2002 (Bill 34) as it relates to the reframing of public educational services and programs as a tradable commodity. It enables public school districts to incorporate private companies to set up offshore schools and to market educational services and programs locally, nationally, and internationally. Policymakers introduced this Bill with the assumption that public educational institutions must compete with other "providers," to sell their services and programs effectively in order to keep revenues at a healthy level to ensure their institutional viability and relevancy. This paper examines the goals, motives, and assumptions behind Bill 34, and, more specifically, the extent to which Part 6.1 of Bill 34 incorporates a market approach to public education as it commodifies public educational services and programs and creates competitive arrangements between public educational institutions.
\end{abstract}

\section{Introduction}

This paper is an attempt to understand some of the multiple and complex effects of globalization on educational policy and policy formation. It stems from our personal concerns about the emergence of a market-oriented approach to educational issues as the dominant paradigm for constructing and implementing public education policy in British Columbia (BC). Despite policy-makers' claims about the need to prepare individuals for competition in the global economy (The Select Standing Committee Report on Education, 2002), we believe this approach subtly expresses a concealed ideological agenda in which

Gérald Fallon is a PhD candidate at the University of Western Ontario and a school administrator of a community school in Nanaimo, British Columbia. Sonya Pancucci is a $\mathrm{PhD}$ candidate at Brock University and a grade three teacher in Hamilton, Ontario. 
the social and economic well-being of individuals is subordinated to that of the corporate sector (Jordan \& Strahdee, 2001; Scholte, 2000).

Under the governmental reform agenda of Premier Gordon Campbell, the School Amendment Act of 2002, better known as Bill 34, altered British Columbia's educational landscape. Some observers (Kuehn, 2002; Nelles, 2001) characterize the implementation of Bill 34 as an unprecedented wave of top-down, rapidly implemented educational reform pursuing these explicit goals:

1. increase the fiscal and academic accountability of public education;

2. eliminate the provincial deficit;

3. make the transition toward a market ideology in many aspects of the public education system;

4. mandate the establishment of school planning councils; and

5. expand parental and student choices to attend any schools and programs anywhere throughout British Columbia.

In order to analyse the ideological assumptions of Part 6.1 of Bill 34 and their potential long-term impacts on public education in $\mathrm{BC}$, this paper is divided into three sections. The first section provides an overview of the context that led to the emergence of Bill 34 and reviews the key policy issues and ideas that prompted a policy development debate and policy response by the BC Liberals. The second part addresses the content of Bill 34 in terms of its key components, general purposes, rights and obligations, and assumptions. The third section discusses more specifically the nature, underlying assumptions and potential long-term impacts of Part 6.1 of Bill 34 on public education. This critical analysis employs policy documents (acts, guidelines, directives), policy review documents (white papers, debates, technical reviews), and relevant research literature drawn from the work of researchers who critique the reconfiguration of public education as a commodity within the context of globalization (Ashton \& Green, 1996; Jordan \& Strahdee, 2001; Robertson, 2000; Scholte, 2000).

\section{Context of Bill 34}

The context in which Bill 34 emerged is characterized by global economic developments and demands that are shaping provincial educational policies into a neo-liberal framework that emphasizes shrinking the state sector while promoting market approaches to school choice and program delivery, rational management of school organizations, performance assessment and accountability, and deregulation in order to encourage new "providers" of educational services (Scholte, 2000). These tendencies are embedded in two 
Table 1 - Key Features of the B.C. 2001 Liberal Election Platform on Education Entitled: "A New Era for British Columbia: A Vision for Hope and Prosperity for the Next Decade and Beyond"

\begin{tabular}{|l|l|}
\hline \multicolumn{1}{|c|}{ Policy Issues } & \multicolumn{1}{c|}{ Proposed Policy Options } \\
\hline Mandate of public education & $\begin{array}{l}\text { To put more computers in schools and increase } \\
\text { resources to improve computer literacy for students } \\
\text { To work with employers and post-secondary } \\
\text { institutions to increase training and apprenticeship in } \\
\text { education is to ensure that } \\
\text { individuals have the skills and } \\
\text { knowledge to compete with the } \\
\text { world's best and win. }\end{array}$ \\
$\begin{array}{l}\text { To strengthen the network of colleges and } \\
\text { institutions and on-line learning } \\
\text { To expand job training and skills development } \\
\text { opportunities }\end{array}$ \\
\hline $\begin{array}{l}\text { Access, choice and flexibility } \\
\text { the flexibility and the resources } \\
\text { to meet the students' needs. }\end{array}$ & $\begin{array}{l}\square \text { give school boards more autonomy and control } \\
\text { over the delivery of educational services } \\
\text { To give school boards multi-year funding } \\
\text { envelopes in order to facilitate long-term educational } \\
\text { planning and budgeting } \\
\text { To entitle parents to volunteer their services } \\
\text { provided it does not result in the displacement of } \\
\text { existing staff service } \\
\text { To create new opportunities and better access to } \\
\text { advanced education through skills training, research, } \\
\text { and development }\end{array}$ \\
\hline $\begin{array}{l}\text { Quality and accountability } \\
\text { public education should } \\
\text { autonomy and financial and } \\
\text { academic accountability. }\end{array}$ & $\begin{array}{l}\text { To establish specific goals and outcomes to } \\
\text { measure the success of educators in public } \\
\text { schooling } \\
\text { To devote more of each dollar to improving the } \\
\text { quality of education and less towards bureaucracy }\end{array}$ \\
\hline
\end{tabular}

main policy documents that form the framework used by the BC Liberals in considering educational matters:

1. The 2001 BC Liberal election document on education entitled: "A New Era for British Columbia: A Vision for Hope and Prosperity for the Next Decade and Beyond"

2. "The Select Standing Committee Report on Education" published on March 28, 2002

Table 1 summarizes the key education policy issues raised by the $\mathrm{BC}$ Liberal platform during the provincial election in 2001: far more variation and choice in the delivery of educational services and programs, greater local community input into how schools are run, transformation of the accountability and professionalism of teachers, and promotion of market approaches to school choice. 
These broad ideas were subsequently turned into a more detailed scheme in the form of a report presented as the result of consultation with different stakeholders (The Select Standing Committee Report on Education, 2002). The mandate of the Standing Committee was to report on measures to improve access, choice, flexibility and quality in public education, and to strengthen the network of colleges, institutes and on-line learning throughout the province. Table 2 outlines the key policy issues and options proposed in this report.

Table 2 - Features of the Select Standing Committee on Education Report 2002

\begin{tabular}{|c|c|}
\hline $\begin{array}{c}\text { Key policy Issues Presented in the } \\
\text { Report }\end{array}$ & Proposed Policy Options \\
\hline $\begin{array}{l}\text { Meaning of public education } \\
\text { Public education is the key to a healthy } \\
\text { and a prosperous economy. Its value is } \\
\text { framed by the need for a highly educated } \\
\text { workforce in order to stay competitive in } \\
\text { the knowledge-based global economy. The } \\
\text { report reflects the societal belief that an } \\
\text { educated population has social and } \\
\text { economic value for the individual and for } \\
\text { society }\end{array}$ & $\begin{array}{l}\text { To link work opportunities and schooling } \\
\text { To improve access to further training and } \\
\text { education for workers and students by } \\
\text { increasing the degree of choice and flexibility } \\
\text { within the current system } \\
\text { To offer alternative non-academic post- } \\
\text { secondary courses and programs } \\
\square \text { To develop specialty or magnet schools that } \\
\text { offer skills courses and programs }\end{array}$ \\
\hline $\begin{array}{l}\text { Current initiatives } \\
\text { Attention should be given to social equity } \\
\text { programs to enable children to take } \\
\text { advantage of the educational opportunities } \\
\text { available to them. }\end{array}$ & $\begin{array}{l}\text { To make these non-education programs an } \\
\text { integral part of the public education system }\end{array}$ \\
\hline $\begin{array}{l}\text { Local involvement } \\
\text { The report underlines the value and } \\
\text { relevance of local initiatives and choices } \\
\text { and the advantage of making educational } \\
\text { decisions close to and in consultation with } \\
\text { those who are affected by the decisions. }\end{array}$ & $\begin{array}{l}\text { To allow institutions to make decisions } \\
\text { reflecting local priorities and needs } \\
\text { To provide opportunities for parental input } \\
\text { into decisions affecting their children }\end{array}$ \\
\hline $\begin{array}{l}\text { Access, choice and flexibility } \\
\text { Students should have access to greater } \\
\text { choice and variety in schooling in terms of } \\
\text { relevant education and training } \\
\text { opportunities. }\end{array}$ & $\begin{array}{l}\text { To increase alternative secondary school } \\
\text { programs leading to non-university degree } \\
\text { programs } \\
\square \text { To increase support for independent private } \\
\text { institutions } \\
\square \text { To develop more alternative public schools } \\
\text { including funded charter schools }\end{array}$ \\
\hline $\begin{array}{l}\text { Quality and accountability } \\
\text { The scope and kind of current } \\
\text { measurements of achievement do not } \\
\text { provide an accurate measurement of the } \\
\text { quality of the public education system. }\end{array}$ & $\begin{array}{l}\text { To set more specific goals and standards } \\
\text { to provide clear direction to the public system } \\
\text { To implement accountability measures that } \\
\text { reward achievement and provide for } \\
\text { intervention where effectiveness is not evident }\end{array}$ \\
\hline
\end{tabular}


This report promotes a public education system that is fragmented and focused on localized educational projects that promote choice and difference over uniformity. It is also conceptualized within and connected to larger global trends of less redistribution and increased market-based competition between schools and other service providers. It promotes the politics of difference as the justification for an emphasis on devolution and school choice based on free-market principles. This report replicates the major orientations outlined in the $\mathrm{BC}$ Liberal election platform on education and was used by the government to frame the political debate that led to the enactment of Bill 34 in May 2002.

\section{Content of Bill 34}

Bill 34 promotes four central ideas:

1. Recognition of parental involvement;

2. More choices for students in terms of schools and educational programs;

3. Greater financial flexibility and accountability; and

4. Use of alternate sources of funding by allowing school boards to set up separate entities to engage in entrepreneurial activities.

Table 3 synthesizes the main elements of Bill 34 in terms of purposes, rights and obligations, and underlying assumptions.

The main characteristic of Bill 34 is the promotion of various types of school choice, including alternative schools, magnet schools, and voluntary transfer and open enrolment plans. The idea of choice is the precursor to the other dimensions of Bill 34 as they embrace:

1. a sharp distinction between academic and vocational routes, thus reversing the trend in the Western world against streaming and tracking, developed in the name of educational equity (Ashton \& Green, 1996);

2. a shift of public education toward competence-based skills at the expense of the more fundamental forms of critical competence for autonomous learning and active democratic citizenship;

3. accountability to the "client" as there is ambiguity with respect to who is the real client-the parents, the students or the potential employers-and who should define the nature of the educational service; 
4. a form of competition among schools that allows those with the most valued cultural capital to commodify it in the educational marketplace, and leaving those whose cultural capital is less valued with far less market power (Gewirtz, Ball, \& Bowe, 1995);

5. an atomized decision-making process as responsibility is shifted to a school-based entity that reduces the scope for collective action to improve education for all (Whitty, Power \& Halpin, 1998).

Table 3 - Overview of Bill 34, School Amendment Act, 2002

\begin{tabular}{|c|c|c|}
\hline Purposes & Rights and Obligations & Underlying Assumptions \\
\hline $\begin{array}{l}\text { Enhancing the } \\
\text { opportunity for } \\
\text { parental } \\
\text { involvement } \\
\text { Part 2, Division } \\
2 \text {, sections } 8.1 \\
\text { to } 8.5\end{array}$ & $\begin{array}{l}\text { Bill } 34 \text { requires the } \\
\text { establishment of a school } \\
\text { council in every school in } \\
\text { British Columbia. } \\
\text { The school planning council } \\
\text { is responsible for drawing up } \\
\text { an annual plan that identifies } \\
\text { the school's strengths and } \\
\text { weaknesses, sets goals for } \\
\text { improvements and monitors } \\
\text { its progress. } \\
\text { The school planning council } \\
\text { can make detailed decisions } \\
\text { about how to allocate } \\
\text { resources within the school. }\end{array}$ & $\begin{array}{l}\text { "The most important } \\
\text { determinant of student } \\
\text { success is parental } \\
\text { involvement" (Hansard, 6(14), } \\
\text { 3005). } \\
\text { Schools need "to be } \\
\text { reconnected to their } \\
\text { community in order to } \\
\text { encourage local responsibility } \\
\text { and accountability" (Hansard, } \\
6(14), 3005) \text {. }\end{array}$ \\
\hline $\begin{array}{l}\text { Enhancing the } \\
\text { freedom and } \\
\text { financial } \\
\text { flexibility of } \\
\text { school boards } \\
\text { to make } \\
\text { decisions } \\
\text { according to } \\
\text { their local } \\
\text { needs. } \\
\text { Part } 6 \text {, } \\
\text { Divisions } 1 \text { and } \\
2 \text { - Part } 6.1 \text {, } \\
\text { Divisions } 1 \text { to } 9\end{array}$ & $\begin{array}{l}\text { School boards may share } \\
\text { administrative services with } \\
\text { other school boards, } \\
\text { municipalities, or corporate } \\
\text { entities. } \\
\text { School boards may dispose } \\
\text { of surplus capital assets and } \\
\text { share in the financial gain } \\
\text { proportionate to their share } \\
\text { of the purchase. } \\
\text { School boards may create } \\
\text { separate entities to engage } \\
\text { in entrepreneurial activities } \\
\text { to market their intellectual } \\
\text { capital. }\end{array}$ & $\begin{array}{l}\text { The creation of competitive } \\
\text { arrangements between } \\
\text { school boards' personnel and } \\
\text { outside "service providers" } \\
\text { bring about a more cost } \\
\text { efficient delivery of services" } \\
\text { (Hansard, 7(12), 3398). } \\
\text { The school boards' ability to } \\
\text { generate revenues through } \\
\text { other sources allow them to } \\
\text { better meet local educational } \\
\text { needs. "There are } \\
\text { opportunities to bring some } \\
\text { money home for BC kids" } \\
\text { (Hansard, 7(7), 3250). }\end{array}$ \\
\hline
\end{tabular}




\begin{tabular}{|c|c|c|}
\hline Purposes & Rights and Obligations & Underlying Assumptions \\
\hline $\begin{array}{l}\text { Holding school } \\
\text { boards } \\
\text { accountable for } \\
\text { financial and } \\
\text { academic } \\
\text { matters. } \\
\text { Part 2, Division } \\
\text { 2, sections79.2 } \\
\text { and } 80\end{array}$ & $\begin{array}{l}\text { School boards must } \\
\text { complete accountability } \\
\text { contracts. } \\
\text { A special advisor may be } \\
\text { appointed to review the } \\
\text { progress of boards where } \\
\text { they are not meeting the } \\
\text { goals of student } \\
\text { achievement. }\end{array}$ & $\begin{array}{l}\text { The school system tends "to } \\
\text { focus on the means of } \\
\text { education without sufficient } \\
\text { attention to the outcomes. } \\
\text { The system is driven by the } \\
\text { interests of the system or the } \\
\text { service provider rather than } \\
\text { the interests of the leamer } \\
\text { and the public" (Hansard, } \\
6(14), 3007 \text { - 3009). }\end{array}$ \\
\hline $\begin{array}{l}\text { Providing } \\
\text { choices in } \\
\text { terms of } \\
\text { schools and } \\
\text { educational } \\
\text { programs. } \\
\text { Part } 6 \text {, Division } \\
2 \text {, sections } \\
74.1 \text { to } 75.1\end{array}$ & $\begin{array}{l}\text { Students will be able to } \\
\text { attend schools in any } \\
\text { catchment area in BC } \\
\text { (subject to space availability). } \\
\text { Schools must be more } \\
\text { responsive to the needs of } \\
\text { their community of learners. }\end{array}$ & $\begin{array}{l}\text { The creation of competitive } \\
\text { arrangements between } \\
\text { schools and school boards } \\
\text { provides them with an } \\
\text { incentive to improve and be } \\
\text { more responsive to their } \\
\text { community of consumers } \\
\text { (Hansard, } 6(14), 3025) \text {. }\end{array}$ \\
\hline
\end{tabular}

The main assumption is that the introduction of market principles and consumer choice into the organisation of schooling will ensure a more efficient delivery of education and enhance its quality. However, some scholars argue that such a policy exacerbates the problems of inequality of educational opportunity, as individuals with cultural and financial capital are able to maximise schooling to their own educational advantage, to the disadvantage of others who cannot (Jonathan, 1989; Ball, 1994; Adler, 1997). The consequence is intensified social segregation as public education becomes a commodified good, one subject to divisibility and excludability (Ball, 1994).

\section{Part 6.1 of Bill 34}

In the context of Bill 34 and within its main feature of educational choice, commodification is the crucial structural effect that illustrates how the neoliberal form of globalization can influence policy making in public education (Scholte, 2000). Part 6.1 of Bill 34 allows public school districts to create legal entities to engage in competitive entrepreneurial activities, such as providing consulting services and educational or administrative expertise and promoting international education through the recruitment of foreign students or the establishment of offshore BC schools designed as profit centres. This part of Bill 34 introduces the institutional dynamics of entrepreneurialism and 
competitiveness in delivering and funding public education. Similar legislation implemented in Australia, New Zealand, the United Kingdom, and the United States has been designed to enable school districts to make up shortfalls in government funding through recruiting foreign fee-paying students, creating offshore private schools, and trading educational expertise and services (Robertson, 2000).

Part 6 of Bill 34 reconceptualizes school districts and their teachers as competitive units within the national and global economies as it is assumed that:

1. school districts should become more "entrepreneurial," that is, be more responsive to and governed by the preferences of the community of consumers they seek to serve in the marketplace;

2. the creation of more competitive arrangements between school districts will deliver better educational services in terms of efficiency, quality, product differentiation, product management, and the capacity to react quickly to consumer needs; and,

3. trading educational services and programs will augment financial resources for public education.

This part of Bill 34 delivers up some aspects of school district activities to the marketplace, whose mechanisms will reshape them toward the requirement of profit-making. The policy option embedded in Part 6.1 looks for school districts to engage directly in revenue-making activities by viewing knowledge as an exportable commodity. The main outcome of such a policy option for school districts is that they could become more instrumentally focused on externally controlled definitions of educational process and product regulated by a market mode. Furthermore, this part of Bill 34 may lead to competition between school districts; it will allow those with the most valued cultural capital in the eyes of choice-conscious parents to market it as an individual benefit to their children rather than as a service to the public, while districts with less valued cultural capital hold far less market power. What takes place within a school district in terms of day-to-day learning and instruction may become less important than the marketing signs and symbols that represent the type of students and parents who choose a given school district and the culture and value system they hold dear. It could lead school districts to act more and more as entrepreneurial units rather than as institutions with social interests and responsibilities (Robertson, 2000). The school districts with the 
most powerful symbols win in the educational market (Gewirtz, Ball, \& Bowe, 1995).

\section{Conclusion}

Academic choices and open enrolment, efficiency through accountability, entrepreneurialism, and competition underpinned Bill 34. Unfortunately, it has set the stage for public education in British Columbia to view knowledge as a commodity and to link, at least partially, the levels of services and of funding of public education to the entrepreneurial success of individual school districts rather than to an equitable distribution of public resources. The logic of the free market is strongly embedded in Bill 34 and market mechanisms are introduced to capitalize upon choice and efficiency the dominant values in British Columbia's current political culture.

It is too early to fully understand how these new institutional dynamics will shape public education in British Columbia in the long term. Bill 34 is barely two years old and further research is needed to gauge its impact on governance and funding, teachers' work and identities, conceptualization of teaching and learning, teachers' identities, organizational structures of school districts, the mandate of public education, and the roles of school. However, we can draw from the experience of countries that have adopted similar policy options and legislation. Studies done in Australia, New Zealand, the United Kingdom, and the United States clearly show that educational policy options based on entrepreneurialism, choice, and competition promote a form of competition between school districts that allow only those with the most valued cultural capital to commodify it in the marketplace, leaving others with limited access to diminishing public and private resources (Delhi, 1996; Kenway \& Epstein, 1996; Robertson, 2000; Wells, Lopez, Scott, \& Holmes, 1999). A design that turns school districts over to market forces and gives parents more choice does little to alleviate social divisions and promote equity, heterogeneity, pluralism, and local needs (Wells, Lopez, Scott, \& Holmes, 1999).

Regrettably, public education in British Columbia is rapidly becoming a commodity, something to be produced, packaged, sold, traded, franchised, and consumed. In this new dynamic, public school districts are forced to compete against each other. The viability of those that do not compete successfully could be threatened. School districts will need to market and sell their expertise and programs effectively in order to keep enrolment and revenue at a healthy level. School districts are being transformed into corporate entities geared toward the ideal of making a profit in a consumer-driven public system based 
on factors such as product differentiation, product management, economic instrumentalism, and the capacity to react quickly to choice-conscious parents.

\begin{abstract}
Authors' Note
The authors would like to thank Dr. Greg Dickinson (UWO) for his helpful comments on an earlier draft of this paper.
\end{abstract}

\title{
References
}

Adler, M. (1997). Looking backward to the future: Parental choice and education, British Educational Research Journal, 23, 297-313.

Ashton, D. \& Green, F. (1996). Education, training and the global economy. Chetlham, UK: Edward Elgar.

Ball, S.J. (1994). Education reform. Buckingham, UK: Open University Press.

BC Liberals. (2001). A new era for British Columbia: A vision for hope and prosperity or the next decade and beyond. Retrieved January $7^{\text {th }}, 2003$, from http://www.bcliberals.com.

British Columbia, Select Standing Committee on Education (2002). A future for learners: A vision for renewal of education in British Columbia.

Victoria, BC: Ministry of Education, Governance and Legislative Unit.

British Columbia. (2002). Bill 34, School Amendment Act - 2002. Victoria, BC:

Ministry of Education, Governance and Legislation Unit.

British Columbia Hansard Services. (2002). Official report of debates of the Legislative Assembly, $3^{\text {rd }}$ session, $37^{\text {th }}$ Parliament, Hansard, 6(14), 2997-3043.

British Columbia Hansard Services. (2002). Official report of debates of the Legislative Assembly, $3^{\text {rd }}$ session, $37^{\text {th }}$ Parliament, Hansard, 6(16), 3086-3089.

British Columbia Hansard Services. (2002). Official report of debates of the Legislative Assembly, $3^{\text {rd }}$ session, $37^{\text {th }}$ Parliament, Hansard, 7(1), 3099-3121.

British Columbia Hansard Services. (2002). Official report of debates of the Legislative Assembly, $3^{\text {rd }}$ session, $37^{\text {th }}$ Parliament, Hansard, 7(7), 3250-3261.

British Columbia Hansard Services. (2002). Official report of debates of the Legislative Assembly, $3^{\text {rd }}$ session, $37^{\text {th }}$ Parliament, Hansard, 7(12), 3377-3424. 
Delhi, K. (1996). Between market and state? Engendering education change in the 1990s. Discourse: Studies in the Cultural Politics of Education, 17, 363-376.

Gerwirtz, S. Ball, S, \& Bowe, R. (1995). Markets, choice and equity. Milton Keynes: Open University Press.

Jonathan, R. (1989). Choice and control in education: Parental rights, individual liberties and social justice, British Journal of Educational Studies, 37, 321-338.

Jordan, S. \& Strahdee, R. (2001). The training gospel and the commodification of skills: Some critical reflections on the politics of skills training in Aoteara/New Zealand. Journal of Vocational Education and Training, 53, 391-403.

Kenway, J. \& Epstein, D. (1996). Introduction: The marketization of school education: Feminist studies and perspective. Discourse: Studies in the Cultural Politics of Education, 17, 301-314.

Kuehn, L. (2002). B.C. Liberal push boards to market education. Teacher: NewsMagazine of the BC Teachers' Federation, 15(2), 1-3.

Nelles, W. (2001) The world of education market comes to Canada: Competition in a trillion dollars global industry. Retrieved January $7^{\text {th }}$, 2002 from http://www.bctf.ca/Education/NoToWEM/ NellesArticle.html.

Robertson, S.L. (2000). A class act: Changing teachers' work, globalization and the state. New York, NY: Falmer Press.

Scholte, J.A. (2000). Globalization: A critical introduction. London, UK: Palgrave.

The Select Standing Committee on Education Report. A future for learners: A vision for renewal of education in British Columbia. Retrieved December $12^{\text {th }}, 2002$, from http:// www.legis.gov.bc.ca.

Wells, A.S., Lopez, A., Scott, J. \& Holmes, J.J. (1999). Charter schools as postmodern paradox: Rethinking social stratification in an age of deregulated school choice. Harvard Educational Review, 69, 172-203.

Whitty, G., Power, S., \& Halpin, D. (1998). Devolution and choice in education: The school, the state, and the market. Birmingham, UK: Open University Press. 
Brock Education

Vol. 13, No. 1, 2003

\title{
Language Awareness in Nova Scotia Schools: An Exploratory Study
}

\author{
David Piper
}

Acadia University

\begin{abstract}
The author conducted a questionnaire survey of language awareness in 358 students studying in Grades 8, 10, and 12 English classes in three rural and three urban schools in Nova Scotia. The main objectives of the study were to learn just how sensitive these students were to key aspects of language prior to any deliberate instruction in language awareness, to obtain new information about levels of natural language awareness as the basis for curriculum development, to uncover significant subject variables in relation to developing language awareness, and to clarify the theoretical distinction between "ordinary" and "critical" language awareness.
\end{abstract}

In his book Awareness of Language: An Introduction, Eric Hawkins (1984), reflected a growing recognition of the educational value of curriculum development and teaching designed to enhance students' metacognitive knowledge about language and communication. For Hawkins, one purpose of teaching for language awareness was to "light fires of curiosity about the central human characteristics of language" and to "make our students' contacts with language...richer, more interesting, and simply more fun." He also viewed language awareness as an antidote to "linguistic complacency" and as a means of heightening students' sensitivity towards the relationship between language use, prejudice, and discrimination (Hawkins, 1984, p. 6).

In the 1990s, the influence of critical theorists like Bourdieu, Foucault, and Habermas, together with a rise in understanding about the close relations between language and cultural identity, led to an evolutionary movement in the field of language education from a concentration on language awareness (LA) to one on critical language awareness (CLA). As a new introduction to the field by Norman Fairclough (1992) established, this was a move away from a mere

David Piper teaches educational psychology and applied linguistics at Acadia University in Wolfville, Nova Scotia. His main scholarly interests include language awareness, the development of selfhood and identity, and transformative educational practice. 
interest in language patterning, or even in the dynamics of everyday language functions, and towards more political awareness of "how language conventions and language practices are invested with power relations and ideological processes" (Fairclough, 1992, p. 7). In a series of theoretical propositions, Fairclough set forth several key educational objectives for critical language awareness. The most general of these was to establish an understanding of language as discourse that both shapes and is shaped by society. This, he believed, would help to foster an understanding of how language plays a central role in the formation of ideological positions and relations of power (1992, p. 8-9).

While the general educational principles and practices relating to teaching for the various levels of language awareness are now well-established, there may be some danger in assuming that children are fundamentally unaware of variations in language before they encounter formal language awareness classes in schools. Several good reasons exist as to why some research on this question might be of value to the field of language education. One reason is the likelihood that students may already be sensitive to various forms of language variation and communicative intent. We might assume falsely, for example, that children are unable to make critical judgements about language in advertising or other media discourses because we lack sufficiently detailed knowledge about how they actually process the language around them. It is even possible that there may be some significant contrasts in qualities of language awareness that are due to generational differences between students and their teachers.

A second reason is that if levels of language awareness are a quite normal part of children's linguistic and social development, then it would be useful to know as much as we can about these developmental processes in order to think with greater precision about appropriate curriculum for language awareness. A third reason is that a more detailed understanding about any significant relationships between aspects of children's natural language awareness and any relevant background variables (such as gender, age, and so on) should provide important grounding for making specific curriculum adaptations within particular language communities. A fourth reason is that understanding natural levels of language awareness that are developed without specific teaching input should help us to clarify the important theoretical distinction between what might be considered to be "ordinary" and truly critical language awareness. A final reason, following Corson's (1997, 1999) advice on the development of language policies in schools, is that there is great value in conducting research and assessment in the contexts of localized discourse communities. One emergent theme in language education is the growing recognition that the essence of human communication lies in the continual and 
creative development of language forms and functions within language communities. As Corson (1999) points out, research undertaken in local communities should lead to important insights for heightening teachers' language awareness in relation to the communicative and academic needs of their students.

This paper reports an exploratory study of children's natural language awareness conducted with the goal of achieving such insights. A survey was conducted of students in Grades 8, 10, and 12, studying in both rural and urban schools in Nova Scotia. The main purposes of the study were to explore students' levels of language awareness and to generate further interesting questions about the relationship between language awareness and teaching practice.

\section{Method}

\section{Questionnaire Development}

Language awareness involves a number of different and quite specific kinds of knowledge about language. At one level, it involves knowledge about structure and grammar and, at another, knowledge about social aspects of language, including language variation, speaker and audience variability, language functions, speaker intent, and contextual code-switching. At a third and even higher level, it involves knowledge about how language can be deliberately manipulated for persuasive effect, a process which most typically takes place in advertising contexts. At the highest level of all, the level of critical language awareness, the focus is on recognition of how social and discourse patterns are mutually constitutive and of how individuals are largely immersed in and conditioned by the language patterns of communities at large.

The study focused on exploring language awareness at the first three of the above four levels (grammatical awareness, sociolinguistic awareness, and advertising awareness). In order to find out more about natural levels of awareness in these various categories, I set out to develop a questionnaire that could be presented in language classrooms as a quite natural (if not regular) part of classroom work in English. From the outset, the intent was to design a questionnaire that would be of interest to students in grades 8,10 , and 12, and that they would not construe as some kind of objective test. For this reason, rather than calling it a "research instrument to determine language awareness," I constructed the questionnaire in the more familiar style of surveys students would likely know from reading popular magazines. The questionnaire bore the title: "How sensitive are you about language?" 
The questionnaire was divided into five main sections, each of which was designed to yield observations about the relationship between the independent subject-background variables and dependent measures of subjects' language awareness. In the first section, students were required to provide data on each of the following: a) gender, b) grade level, c) time spent watching television, d) time spent on computers and the Internet, and e) time spent reading for enjoyment. In the context of this limited exploratory study, however, it was felt that these were promising initial items on which to build further research and analysis.

In the second section, targeting grammatical awareness, students were asked to respond to the general question, "How sensitive are you about the mistakes people make in using language?" Here students were asked to make judgements about a series of expressions which were either grammatical in form or which contained some well-known error. Examples included: The school principal spoke to the parents (correct), Celine Dion is a more better singer than Shania Twain (incorrect duplicate comparative), and Brad Pitt is act in a new movie (incorrect verb phrase). In addition to circling "right" or "wrong" for each expression, students were further invited, if they felt like it, to circle the place in the expression where any mistake occurred.

In the third section, targeting sociolinguistic awareness, students were asked to try to recognize a variety of English accents. They listened to six recorded examples of English accents featuring speakers from a) the Southern United States, b) Nova Scotia, c) Jamaica, d) Southern England, e) Australia, and f) a northern Canadian (Inuit) region.

In the fourth section, also on sociolinguistic awareness, students were asked to listen to some further speech examples that had been recorded by a number of university linguistics students who volunteered for the study and who possessed both good acting abilities and sophisticated levels of language awareness. These samples were all based on dialogues between a young adult male and a young adult female whose language use was systematically varied to reveal distinctions between informal and formal English and key distinctions in speaker intent. Three communicative situations were used-a wedding, an office meeting, and a cooking class-yielding six dialogues (wedding formal/ informal; meeting formal/informal; cooking class formal/informal). Following the general question "Can you recognize the language people use in different situations?" students were asked to judge whether they thought the speakers were using language informally, formally, or very formally and whether the speakers' relationship to each other appeared to be very friendly, friendly, or not friendly. They were further asked to make judgements about aspects of the speakers' motivations. For example, in the two wedding party dialogues, 
students were asked whether they thought the male spoke in a way that suggested he did or did not want to get to know the female better and whether they thought the female was enthusiastic or otherwise about the male. In the two cooking class dialogues, subjects were given choices about the nature of the relationship between teacher and student, and in the meeting dialogues they were asked to make judgements about the extent of agreement achieved between the speakers. In order to bring as much content-validity as possible to these dialogues, they were developed through several trials and subjected to prior evaluation by student teachers taking the same course in Applied Linguistics.

Finally, in the fifth section, which explored students' advertising awareness, students were asked to respond to some questions about two genderbased advertisements selected from popular magazines. In the first advertisement, designed to persuade readers to join the armed forces, the head and shoulders of a young woman in the uniform of the United States Marines were portrayed, together with the following caption:

You can change the shade of your lipstick, or you can change your life. Because the changes you make on the inside are the ones that will last forever. Changes that build character. Take you further. Get a make-over that's more than skin deep.

In the second advertisement, designed to persuade readers to buy Preferred Stock cologne, the head of a young man is portrayed juxtaposed to the text:

Preferred Stock: What Preferred Men Prefer-a Man's Cologne from the House of Stetson.

As a basis for developing measurements of subjects' language awareness in response to these advertisements, the texts received prior evaluation, once again, from the 25 students in the linguistics class. Following discussion, multiple-choice questions were developed for the survey designed to test students' abilities to make judgements about the use of certain key words. An example from the Marines' advertisement was the word lipstick, and students were asked to select from the following alternative readings:

The word LIPSTICK is used (Circle a letter)

a .to suggest that women are generally feminine and weak.

b. to suggest that women are attractive when they wear make-up.

c. to suggest that women who use make-up are stronger and smarter.

d. all of the above. 
Similar interpretive choices were given for the keywords change and forever. In the case of the advertisement for cologne, keywords chosen were both preferred and stock, and questions explored subjects' awareness of the associations between these terms and ideas about masculinity and privilege. Again, measures were based on the judgements made by members of the linguistics class prior to the final design of the questionnaire.

\section{Survey Procedure}

In all, 358 students in a total of eighteen Grade 8, 10, and 12 classrooms across six schools (three urban and three rural) completed the survey. Classes were selected for research on the basis of their having no prior experience of direct instruction in language awareness. Before completing the questionnaires, students were informed that they would be participating in an objective survey on sensitivity to language, and that no academic assessment would be based on their responses. They were told not to place their names on the response booklets, and that all responses were voluntary and confidential. All sections of the questionnaire were read out loud to students by a research assistant, and students were able to follow the text themselves. Time to complete each section was flexible and, as promised at the outset, time was also provided at the end of each class for discussion about any questions students might have about the survey or about language in general.

\section{Data Analyses and Findings}

In preparation for statistical analysis, the independent background data were coded, and scores were assigned for the dependent measures of performance for grammatical awareness, sociolinguistic awareness, and advertising awareness. The data were then analyzed using a number of regression techniques. In a first analysis, the general relationship between the subject (independent) variables and subjects' total scores for language awareness were collapsed across the three awareness subcategories. The regression coefficients for the analysis of total scores revealed a highly significant general relationship between dependent and independent variables $(F=14.526 ; p<.001)$ suggesting, in very general terms, that the data on subjects' backgrounds could be used to predict variations in the dependent measures in a reliable and powerful manner. This first overall analysis also revealed that the best predictors of overall score in language awareness were, in order of significance, grade level $(F=5.5 ; p<.001)$, reading frequency $(F=4.47 ; p<.001)$, and computer use $(F=3.5 ; p<.01)$. 
Following this, several separate multiple regression analyses of variance (ANOVAs) were performed on the independent measures and each of the dependent variable categories taken in turn. The second analysis, on grammatical awareness, also revealed a measure of overall significance, together with gender and residential area (urban vs. rural) as the best predictors of performance. The third analysis, on sociolinguistic awareness, yielded an indication of overall significance, together with grade level, reading frequency, and computer use as the main predictors. Finally, a fourth analysis, on advertising awareness, also yielded a measure of overall significance together with reading frequency as the main predictor of success (in significant effects reported here, $p<.01$ ).

To explore the meaning of the results, further post-hoc Tukey tests were performed on mean scores. From this, several interesting findings emerged: First, an interaction appeared in which, while Grade 8 and 10 students in the urban schools obtained higher overall scores than their counterparts in the rural schools, the rural school students scored higher than urban students in Grade 12.

Table 1 - Mean (rounded) percentage scores for overall language awareness: Grade Level and Area of Residence

$\begin{array}{lccc}\text { Area } & \text { Grade } 8 & \text { Grade } 10 & \text { Grade } 12 \\ \text { Rural } & 58 & 59 & 70 \\ \text { Urban } & 60 & 62 & 66\end{array}$

Second, reflecting a well-recognized pattern in language education, girls showed more language awareness in the lower two grades, but were about equal to boys by Grade 12. More detailed analysis showed, however, that grammatical awareness was the major contributor to this effect.

Table 2 - Mean percentage scores for overall language awareness: Gender and Grade Level

\begin{tabular}{|c|c|c|c|}
\hline Gender & Grade 8 & $\underline{\text { Grade } 10}$ & Grade 12 \\
\hline Male & 52 & 58 & 67 \\
\hline Female & 56 & 63 & 69 \\
\hline
\end{tabular}


Perhaps surprisingly, the boys in the study, living in both rural and urban areas, scored higher than the girls for sociolinguistic awareness (accent recognition and contextual analysis combined).

Table 3 - Mean percentage scores for sociolinguistic awareness: Gender and Grade Level

\begin{tabular}{|c|c|c|c|}
\hline Gender & Grade 8 & $\underline{\text { Grade } 10}$ & Grade 12 \\
\hline Male & 54 & 60 & 72 \\
\hline Female & 48 & 58 & 64 \\
\hline
\end{tabular}

One other finding of interest was that boys who reported higher amounts of television-watching and computer-use also scored higher for advertising awareness, while quite the opposite effect appears true for girls.

Table 4 - Mean percentage scores for advertizing awareness: Gender and Time reported spent with media (television-watching and computer-use combined)

$\begin{array}{lcc}\text { Gender } & \text { Less than } 10 \text { hours } & \frac{\text { More than } 14 \text { hours }}{\text { Male }} \\ \text { Female } & 55 & 62 \\ 64 & 52\end{array}$

\section{Discussion}

Overall, the results suggest that students come to their English classes with many kinds of language awareness in place. The purpose of the questionnaire survey was exploratory; its most important contribution lies in suggesting lines of further inquiry, in promoting further meaningful questions about approaches to language awareness in classrooms and schools, and, following Corson's (1999) proposals for justifying the development of language policies in schools, in gauging what can be learned from the actual practice of conducting language awareness research in a given language community (Nova Scotia).

In keeping with the intentions, the survey raised a number of questions for further research about the particular patterns of natural language awareness in these students. Considering the responses as a whole, it appears that school students develop in language awareness as a quite natural part of their cognitive and social development. The study also suggests, though, that English classes focused on language awareness enhance the varieties of students' language 
experiences and thus support their developing awareness. One interesting related question for further research concerns the different sociolinguistic contexts of rural and urban areas in relation to the variety of students' language experiences. Could it be, for instance, that rural students' language awareness might be enhanced by ensuring greater exposure to the broader range of language varieties and communicative intentions found in urban settings? Another question concerns the relationship between children's experiences with the media, including television and computer-based communications, and their language awareness. The findings in the study also suggest that some further research is needed on how best to integrate work on language awareness with children's explorations in virtual communicative contexts on the Internet. It seems possible that children's experiences in the virtual communities of cyberspace may provide rich sources for the development of language awareness. Yet other interesting questions centre on possible differences in style and communication between generational language communities (i.e., teachers and their students, and on the different ways in which girls and boys respond to, interpret and utilize information gained from watching television and using computers.

Although each of these specific questions might lead to worthwhile lines of research in the future, some of the indirect findings from the research may have as much significance for developing curriculum in language awareness. Two common observations made by those collecting the research data were of the genuine interest of many students in exploring these aspects of language awareness and of the overall sharpness of their observations about the complex relations between language, identity, and speaker-intent. From the perspective of curriculum development for language awareness, these interactions, together with the overall scores in the survey, leave little doubt that teachers have a rich and natural base of student background knowledge and interest to work with.

In his summary of some of the current main objectives in teaching practice for language awareness, Corson (1999) identified nine central "areas of knowledge," including knowledge of the patterns of language, different styles or varieties within students' own language, knowledge that other varieties of their own languages are used in different societies (or dialect areas), and knowledge about the use of different styles of English for different purposes (Corson, 1999, p. 135-142). The survey results in this study suggest that many students in Nova Scotia's schools are already knowledgeable in many of these areas and that their growing awareness about language provides a rich base for curriculum development and teaching. The findings also suggest that researchers are likely to find certain significant subject variables within each language community 
studied-variables such as gender and area of residence-that can be seen to affect levels and rates of development in language awareness.

Finally, the question remains about the relationship between the foundation of students' natural development of language awareness and later teaching for critical language awareness. This study suggests that many students already have levels of language awareness that are prerequisite to higher and more critical levels of response. It also raises the question of how "critical" language awareness should be distinguished from the so-called lower levels of language awareness. A detailed treatment of this question lies beyond the scope of this exploratory survey, but a satisfactory answer would seem to depend, among other things, on a more precise definition and understanding of what the term "critical" actually means in this context. As this study suggests, many students already have a natural ability to recognize at least some of the ways in which advertisers make deliberate language choices as part of their techniques of persuasion. In this way, it seems that the students are already sensitive to some of the ways in which language can be deliberately manipulated for effect. What remains to be explored, however, is just how this kind of language awareness provides the basis for the further cognitive leap into awareness of the more complex relations between language, identity, and social organization.

Perhaps the most significant question of all, though, is that of whether one can claim that a level of "critical" language awareness can be fully distinguished over and above the kinds of language awareness explored in this study. If "critical" is to be understood as a form of politically-oriented language awareness (Fairclough, 1992), then a pedagogical contradiction arises: On the one hand, education for language awareness is motivated by an interest in opening up new questions about relations between language, identity, and society but, on the other, the view of language as essentially "political" in nature brings with it its own forms of conceptual foreclosure. The latter danger is particularly apparent in "critical pedagogical" approaches to language awareness, in which the interpretation of "political" is already infused with connotations of "resistance" and "liberation." This study suggests that there may be more to be gained in language education by exploring actual levels of language awareness in particular communities, and by building on these levels, rather than by introducing conceptualizations of "critical" language awareness that themselves give rise to skepticism and doubt. 


\section{References}

Corson, D. (1997). Awareness of non-standard varieties in the schools. In L. van Lier \& D. Corson (Eds.), Knowledge about language: Encyclopedia of language and education (Vol.6) (pp. 229-240). Dordrecht: Kluwer Academic Publishers.

Corson, D. (1999). Language policy in schools: A resource for teachers and administrators. Mahwah, NJ: Lawrence Erlbaum Associates.

Fairclough, N. (Ed.). (1992). Critical language awareness. London, England: Longman.

Hawkins, E. (1984). Awareness of language: An introduction. Cambridge: Cambridge University Press. 


\section{BOOK REVIEW}

\section{Understanding Curriculum: An Introduction to the Study of Historical and Contemporary Curriculum Discourses}

W. F Pinar, W. M Reynolds, P. Slattery, \& P. M. Taubman. New York: Peter Lang Publishing Inc., 2000

\section{Reviewed by Kenneth A. McClelland, Brock University}

When it comes to educational tomes, it would be hard not to recommend Understanding Curriculum (Pinar, Reynolds, Slattery, \& Taubman, 2000). The book offers a thorough overview of the last 150 years of curriculum thought and is organized in such a way that, although lengthy (nearly 1000 pages), it is palatable to both the generalist and the specialist. I would recommend this text unhesitatingly as a breakthrough work of scholarship and as an invaluable guide through what can seem to the weary traveler a bewildering curriculum landscape.

Understanding Curriculum (Pinar, et al., 2000) provides a sense of the sheer diversity of the curriculum field and the challenge this diversity poses for democratic community building, although one has to read between its many lines to infer this democratic spirit. In the first place, the text is comprehensive in scope, dealing with over a century's worth of curriculum development and understanding. Indeed, the text is broadly divided into two parts-curriculum "development" and curriculum "understanding." For it is not just a survey of curriculum thought, but also an attempt to define in a rigorous way the disciplinary parameters of curriculum study. The authors do this by showing the diversity of the educational conversation carried on over the past century.

In turn, this diversity is treated as an essential feature of curriculum as a discipline. The book, as well as being an invaluable historical survey, is also self-reflexive-labouring consistently to formulate and clarify the internal rationale of the discipline it is surveying. I found the text noble for this reason, but not without its tensions.

One of the most prominent tensions in the text arises from the attempt to reconcile the autonomy of curriculum study as a discipline with many often competing and acrimonious voices. Amidst all the diversity of voices that makes curriculum study so adventurous and energizing, the reader seeks some deeper meaning, a nobler ideal that is weighty enough to be commonly striven for. 
My own bias, if it can be called that, is unabashedly Deweyan, and to this extent I am always on the lookout for how and to what degree texts like this one foster and attempt to enliven democratic practices. Sadly, in Understanding Curriculum, democratic practice is conspicuously absent as a working ideal. I say as a working ideal, because although democracy is mentioned frequently, it is always as part of the survey aspect of the book. It is presented as a theme within the many competing academic and cultural discourses, but not as an informing ideal for the whole book. I think it is there implicitly, but it is as if the authors are hesitant to express it openly lest their book appear to hold a cultural preference for a democracy narrative which might appear incompatible with a post-modernist agenda.

In a way, then, the book succumbs to an internal tension between taking diversity and plurality as its motivating energy and attempting to avoid an overly fragmented discourse that would make it extremely difficult to define curriculum study as an autonomous discipline. This tension is manifest in the final pages of the book's last chapter, "A Postscript for the Next Generation." Here, where the authors speak as and for themselves, where they sum up what they and their book have attempted to show, the word "democracy" is mentioned explicitly only twice, and one of these is in a negative light. The negative reference shows the tension that exists between "defining with" and "defining against."

The reference comes in a commentary on the work of Henry Giroux. Here, the authors highlight what they view as an imminent conceptual shift in curriculum theorizing. The parent theoretical disciplines from which contemporary curriculum theory descends (social theory, phenomenology, feminist theory, race theory, etc.) and from which it derives its own telic impulse, are now exhibiting highly porous boundaries that allow curriculum theory to at once move away from its parent disciplines and gain its own sophisticated conceptual voice expressed in a more nuanced interdisciplinary conversation. This healthy hybridization they find potentially expressed in Giroux's notion of "bordercrossings."

Giroux's notion of bordercrossings (1992a) might apply here, in one sense, that is, of moving easily across borders that before seemed to employ customs agents. For true hybridization to occur, however, the identity of the traveler must fuse with those with whom he or she travels and visits. (Pinar, et al., 2000, p. 853) 
I quite like the subtle image of the identity of the traveler fusing with those he or she visits. But note how the authors define such identification negatively as they go on to point out that Giroux's notion of "bordercrossings" is only halfhearted, because he has not sufficiently moved away from what are now, apparently, the antiquated themes and language of "critical pedagogy."

[Giroux] can be said to have moved from a nearly exclusive political emphasis to concerns for curriculum as racial and gendered text, but these later aspects seem to be, in the context of his opus, "add-ons." That is, the basic theses do not seem to have changed much from the "language of possibility," struggling for a more democratic public sphere, resistance to the status quo, and so on. Giroux seems to have "added on" concerns for race, gender, and postmodernism in his most recent writing, leaving intact his core theme of "critical pedagogy." (Pinar, et al., 2000, p. 854 [italics mine])

In this comment on the recent work of Giroux, the authors imply that the political militancy associated with critical theory was a necessary "violent" phase in the paradigm shift from "development" to "understanding" in curriculum thought, a phase which has now passed. Quite apart from the validity of their comment, this reader is dumbfounded by the authors' language: If the identity of the traveler, that is, the next generation of scholars, is to fuse somehow with these multiple postmodern "others," then what in the world will this identity look like when 'the language of possibility,' 'struggling for a more democratic public sphere,' and 'resistance to the status quo' are deemed antiquated notions? What am I missing here? Are we to assume that the language of possibility has been realized, that a democratic public sphere has been achieved, and that the status quo has been overcome? If we are to assume this, then can we abide by such a comfortable assumption? Perhaps this is not what the authors are implying. My sense is that in attempting to situate curriculum study within its own autonomous theoretical matrix, the authors have inadvertently employed a reckless choice of words, which is expressive of the tension within curriculum theorizing between what I am calling "defining with" and "defining against." Curriculum theory's own crisis of identity spills out in the above-cited passage as the authors equate democracy with a brand of institutional politics and fail to offer a broader understanding of what contemporary democratic struggle might look like. This is representative of the kind of postmodern fumbling that wishes to latch onto everything, but cannot find a way of adopting any explicitly informing ideals that would provide some 
integrating moral glue. If democratic struggle is not a vital component of identifying with others in a more deeply meaningful way, then what is? What finally are the stakes of this burgeoning educational conversation?

If democratic practice is a worthy ideal, then this ideal has not been conceptually fleshed out enough in the postmodern landscape. It is as if it is too much a part of the business of modernity to take up in a serious and rigorous way. However, there is ample business of the modern that is far from being settled. To take up Dewey's project, for example, in a more comprehensive way than has been done amongst curriculum thinkers, is to take up this unsettled business. The rush of many postmodernists has prematurely deemed much already settled. The rest is just the job of sophisticated conceptual clarification. But does not such conceptual sleight-of-hand, popular amongst many postmodern thinkers, also run the danger of potentially re-silencing many voices? In attempting to gain an identity, is not much curriculum theory recolonizing a vast terrain, only this time with a kinder and gentler discourse? What I sense is a sliding away from "defining with" to "defining against." The balance is shifting dangerously, and there appears to be a diminishing of the merits of real democratic struggle in the concrete world. And so I ask, "So what?" What ideals will bind the terms, sophisticated in understanding as they might become, of the multi-vocal conversation that will allow curriculum thinking to identify itself? What shall it talk to itself about, and who will struggle, and who will feel it not as a struggle? Is the real world awaiting conceptual reconstruction or concrete action? 